\title{
CASINO CAPITALISM? THE IMPACT OF FINANCIAL CRISES ON INEQUALITY, 1970 TO 2016
}

\author{
Frederike Rübsam ${ }^{1}$ and Gerald Schneider ${ }^{2}$ \\ University of Konstanz
}

The ways in which countries have reacted to financial crises varies considerably. While income inequality has grown in more than half of the EU member states after the Great Recession, some countries such as the United States have experienced a significant increase in wealth inequality. A number of countries, by contrast, was able to keep these inequities at bay. We argue in this paper that the impact of financial crises on inequality differ between the type and severity of these economic shocks and that sovereign debt and exchange rate rather than banking crises increase the economic inequities. The paper also examines the extent to which fiscal constraints of governments and membership in the Eurozone mediate these effects. We examine the diverse income and wealth inequality effects to more than 50 financial crises across the OECD member states from 1970 to 2010. The empirical evidence gathered so far supports our conjecture of different distributive effects of varying types of crises.

Paper prepared for presentation at the virtual Annual Conference of the American Political Science Association, September 10-13, 2020. We would like to thank Stephan Maurer for comments and Mark Kapteina, Mario-Konstantin Pless, and Sabrina Thillmann for research assistance. The authors acknowledge funding by the Deutsche Forschungsgemeinschaft (DFG - German Research Foundation) under the Excellence Strategy of the German federal and state governments - EXC-2035/1 - 390681379.

\footnotetext{
${ }^{1}$ Research associate at the Department of Politics and Public Administration and the Cluster of Excellence "The Politics of Inequality"

${ }^{2}$ Professor of International Politics at the Department of Politics and Public Administration and the Cluster of Excellence “The Politics of Inequality”, University of Konstanz, Germany. Email: Gerald.Schneider@uni-konstanz.de.
} 


\section{INTRODUCTION}

Do financial crises affect economic inequality in a systematic way? The Keynesian notion "casino capitalism” suggests that capital owners might be the main losers of financial stress. Speculators accordingly receive the deserved bill for their free-wheeling when their money is burned up in the aftermath of stock market crashes or financial market breakdowns. ${ }^{1}$ The historical evidence, however, suggests that capital owners might not suffer under the outfalls of a financial shock as much as one would think. Atkinson, Piketty, and Saez (2011) report that the Great Depression reduced "inequality at the top" in many countries, but that the rich grew, at least relatively speaking, richer in some countries like Canada and Ireland (p. 64). Piketty and Saez (2013) argue for the Great Recession that it "seems unlikely to reverse the long-run trend” of growing inequality (p. 458).

This article addresses this puzzling variety of outcomes, arguing that the effect of financial crises is mediated by the type of shock and the ideology of the government in charge of the rescue measures. Our theoretical framework suggests that currency crises increase the risk of both growing income and wealth inequality, while the impact of banking, inflation, and sovereign debt crises crucially depend on the management of the crises and the political orientation of the crisis managers. When a currency is under attack, governments often introduce capital controls and other restrictive measures. However, capital owners protect themselves against the risk of losing money through pre-emptive hedging or moving to safer markets segments, whereas workers cannot shield themselves against the income loss that a deprecation brings to their purse. Such stark differences between capital and labour do, by contrast, not exist for the other types of financial crises. In addition, governments and central banks can ease the tension between the contending forces about which side should shoulder the pain of adjustment (Alesina \& Drazen, 1991; Genovese, Schneider, \& Wassmann, 2016).

Building on datasets by Hammar and Waldenström (2017), Reinhart and Rogoff (2011) and Laeven and Valencia (2018) as well as the World Inequality Database (Alvaredo et al., n.d.), we construct an unbalanced panel covering, where possible, the 36 OECD states over a period from 1970 to 2016. The sample provides information on post-tax income and wealth inequality as well as the occurrence of the four types of financial crises by year. We use a difference-indifferences (DD) framework to estimate the effects of each crisis type on income and wealth inequality. We find no evidence for an effect of banking crises on either type of inequality. In

\footnotetext{
${ }^{1}$ Keynes (1936) believed that the short-term orientation of speculators contradicts the long-term interests of an economy and famously wrote: "When the capital development of a country becomes a by-product of the activities of a casino, the job is likely to be ill-done” (p. 159). The short-hand "casino capitalism” appears in monographs by Strange (1986) and Sinn (2010), among others.
} 
line with our expectations, currency crises increase income inequality, measured by a Gini coefficient based on yearly net labour earnings. The results also provide indicative evidence that wealth inequality, measured by the wealth-to-income ratio in a country, decreases due to currency and inflation crises. Inflation crises have no effect on income inequality, however. Finally, the results imply that sovereign debt crises decrease income inequality in the few countries covered by the sample that go through this type of crisis. However, the robustness checks show that the interaction with other crisis types plays an important role and that drawing generalizable conclusions regarding the effect of debt crises is difficult. Overall, the effect of financial crises on economic inequality thus depends in light of our hypotheses on the type of crisis, while the impact of government ideology on the crisis-inequality nexus remains unclear.

\section{DIRECT AND INDIRECT LINKS BETWEEN CRISES AND INEQUALITY}

The study of the impact of financial crises and inequality has largely focussed on the Great Depression and the Great Recession. Freeman (2010) observes for the United States that the Great Depression reduced inequality, but that the Great Recession increased it. Piketty and Saez (2003) agree that income fell after the Great Depression. After the Great Recession, however, wealth inequality quickly rebounded following the initial squeeze. The detailed study by Kuhn, Schularick, and Steins (2020) confirms this pattern. According to them, wealth inequality is "a race between the stock market and the housing market” (p. 3502). Housing booms benefit the middle class who have wealth in real estate. They are thus associated with decreasing wealth inequality. The rich, on the other hand, have more wealth in stocks, leading to increasing inequality in the case of stock market booms. Since in 2008 housing prices collapsed whereas the stock market boomed quickly again, wealth inequality increased in the US. In Europe, income inequality increased at the start of the Great Recession, but economic recovery turned this development around, with inequality reductions being observed in more than half of the European countries (Vacas-Soriano \& Fernández-Macías, 2018).

The literature points to the importance of institutions and policies in influencing the relationship between financial crises and inequality (Freeman, 2010; Vacas-Soriano \& FernándezMacías, 2018). To account for divergent impact of crises on inequality, we examine in this article the effects of different types of crises and the role government ideology plays in the crisis management. The Great Recession hit the economies not only differently, but the affected countries also experienced a broad variety of financial stress, ranging from banking crises and currency crises to sovereign debt crises or a mixture of different crisis types. 
Banking crises: Banking crises typically manifest themselves in bank runs or banking policy interventions (Bordo, Eichengreen, Klingebiel, Martinez-Peria, \& Rose, 2001; Laeven \& Valencia, 2018; Reinhart \& Rogoff, 2011). This suggests that this type of crisis affects capital owners in the beginning, but that government interventions and other crisis attributes might cancel out the initial inequality reduction. Without making clear predictions as to the direction of the effect, Honohan (2005) and Brown (2013) list a variety of channels through which banking crises can affect inequality. Households may be impacted through the labour market. A banking crisis can lead to reduced production and investment following credit crunches-referring to banks' limited willingness to lend-and thus to reduced wages and even job losses. Brown (2013) claims that the construction and manufacturing sector is most directly impacted via this channel, leading to a stronger effect on poor households in urban areas than on others. Households can also be affected more directly through the credit market if credits and mortgages are limited or distributed at higher lending rates and credit flows are interrupted. Additionally, if creditors of banks lose deposits due to the crisis, this reduces wealth directly. However, Brown (2013) argues that this is unlikely due to depositor insurance. Finally, if a government decides to bail out the troubled banks, taxes can increase or public spending decrease in order to finance these bailouts.

It is in this light not surprising that the literature on the effects of banking crises comes to inconclusive results. Roine, Vlachos, and Waldenström (2009), Lopez (2003), and Honohan (2005) find that banking crises reduce inequality. Roine et al. (2009) use banking crises as a proxy for (retrogressive) financial development. They argue that financial development increases inequality because it benefits insiders (top income earners) more as they can influence said development in a way that is beneficial to them. Banking crises, to the contrary, thus reduce inequality. Honohan (2005) claims that the formal sector is hit more directly by banking crises than other sectors, leading to falling wages especially for the high skilled and thus leading to reduced inequality. Additionally, the income distribution should improve considering that the financial sector is ideally reformed following a banking crisis. Brown’s (2013) empirical results, however, indicate that income shocks are "largely independent of households' (...) income-level” (p. 18). Similarly, Morelli (2018) finds no systematic impact of banking crises on top income shares in the US history. Finally, Atkinson and Morelli (2011), who study 25 countries, observe rising inequality after banking crises. They refer to fiscal consolidation financed through welfare state cuts as an explanation for this observation.

The theory and evidence for the effect of banking crises on wealth inequality in the literature are very slim. The findings by Kuhn et al. (2020) suggest that the effect depends on whether 
the banking crisis impacts the stock market or the housing market more. We nevertheless contend that banking crises affect the financial market more and thus affect the wealth of the rich disproportionately. As the rich profit from financial development, they also lose more of their wealth in the aftermath of a banking crisis (see also Roine et al. (2009). Both wealth and income inequality should thus decline following banking crises.

H1: Banking crises (a) decrease income inequality and (b) decrease wealth inequality.

Currency and inflation crises: It is widely recognized that inflation and currency depreciation often coincide. Baldacci, Mello, and Inchauste (2002) show that consumer price inflation increased considerably in the years in which currency crashes occurred. The predictions regarding the effect of currency and inflation crises on inequality are thus similar. The evidence assembled by Gokmen and Morin (2019) indicates, however, that the effects on income inequality are not the same for the two crisis types. Even though the thresholds vary, currency crises are usually defined as strong depreciations of a local currency versus some anchor currency (Laeven \& Valencia, 2018; Reinhart \& Rogoff, 2011). Theoretical and empirical evidence suggests increasing income inequality and decreasing wealth inequality as a result of currency crises (Baldacci et al., 2002; Bohoslavsky, 2016; Galbraith \& Jiaqing, 1999). Generally speaking, the export sector of an economy should benefit from a currency crisis while its import-competing counterpart loses (Baldacci et al., 2002; Brown, 2013). However, Galbraith and Jiaqing (1999) argue that low-wage workers suffer the most from currency crises. Baldacci et al. (2002) outline how the crises negatively affect the poor. Domestic food prices increase following a price increase of imported foods. The government may cease to provide social services following fiscal retrenchment. Furthermore, slowing economic activity can lead to falling earnings in both the formal and the informal sector. If, as a result, unemployed workers from the formal sector then enter the informal sector, the latter will be particularly affected. The authors also point out that changes in the value of assets affect the wealth of the richer parts of society more negatively than the poorer parts. Bohoslavsky's (2016) arguments are in line with this. He shows that the labour share falls following currency crises, implying "consistently growing income inequality, as a falling [labour] share means that an ever-larger share of the benefits of growth accrues to owners of capital” (p. 190). Summing up, the literature predicts income inequality to increase due to currency crises. Wealth inequality, on the other hand, is more likely to decrease. ${ }^{2}$

\footnotetext{
${ }^{2}$ We control for the possible effect that inflation has on the wealth of lenders vs. borrowers through the usage of fixed effect models.
} 
Reinhart and Rogoff (2011) define an inflation crisis as an annual inflation of at least 20 percent. The literature generally shares the opinion that inflation crises are followed by increasing income inequality, too. Gokmen and Morin (2019) claim that their results, though statistically insignificant, suggest this. Lopez (2003) writes that "inflation is a penalty for the poor and that countries with lower inflation would have a tendency to be more equal” (p. 17). Similar to currency crashes, inflation crises are detrimental for the income of the worse-off due to reductions in earnings and increasing food prices (Baldacci et al., 2002; Bohoslavsky, 2016). We follow the currency crisis logic in our prediction for the effect of inflation crises on wealth inequality: changes in the values of assets affect the wealth of the rich disproportionately, leading to decreasing wealth inequality.

H2: Currency and inflation crises (a) increase income inequality, but (b) decrease wealth inequality.

Sovereign debt crises: Bohoslavsky (2016) argues that sovereign debt crises, which manifest themselves through defaults or massive debt restructurings (Laeven \& Valencia, 2018; Reinhart \& Rogoff, 2009), lead to increasing inequality. According to his logic, the fiscal consolidation and policy measures implemented independently by the governments in charge or in accordance with International Monetary Fund (IMF) bailout conditions in response to the crises have strong distributional impacts - with an observable increase in inequality and a fall of the labour share. He also lists social spending cuts and an increasing unemployment rate as consequences of the crises that increase income inequality. Another channel through which debt crises affect inequality levels is through the decline in output that goes hand-in-hand with the crises. Evidence by Alesina, Favero, and Giavazzi (2018), who discuss public policies to reduce debt, suggests that the effect of debt crises depends on whether states react by cutting spending or by increasing taxes. Whereas cuts of social spending might hurt the poor more, tax increases could be more disadvantageous to the better off.

Obviously, similar mechanisms should also work for wealth inequality. Yet, no country for which we possess data on the wealth-to-income ratio, experienced a sovereign debt crisis for our period of examination.

H3: Sovereign debt crises increase income inequality. 
Government partisanship: As financial crises threaten the survival of the incumbent government, political executives can rely on fiscal and monetary instruments to counteract to economic outfall. However, most of these measures have distributional effects. The resulting conflict between the contending social forces on who should shoulder the larger share of the adaption costs frequently delays the implementation of the reforms (Alesina \& Drazen, 1991; Genovese et al., 2016). In these conflicts, governments are not neutral bystanders but have to juggle the costs of a reform against the potential loss of support among voters.

The partisanship literature, introduced through the pioneering studies by Hibbs (1977), Nordhaus (1975), and others, has, however, established only inconclusive results whether government ideology matters in the design of the reforms in the aftermath of a crisis. ${ }^{3}$ Scheve and Stasavage (2009) find in a sweeping analysis that left governments had little effect on wealth inequality in the long run. However, economic crises have led in some cases to institutional innovations that have reduced inequality. Huber, Huo, and Stephens (2019), by contrast, show that both partisanship and institutions affect inequality substantively: “(...) a two standard deviation change in secular center and right government increases the share of the top $1 \%$ by some 1.75 percentage points and union density reduces the top $1 \%$ share by more than 2.5 percentage points” (p. 246).

The distributional effect of financial crises affects wage inequality largely through reforms of the income tax. Limberg (2019) shows that countries affected by financial crises from 2006 and 2014 increased their marginal top rate by 4 percent at the average. He also reports in the supplementary material that left cabinets are associated with higher progressivity, but does not interact this partisanship variable with the occurrence of crises.

H4: Leftist governments reduce the inequality growth in the wake of a financial crisis.

As financial crises have strong economic effects, we need to control for the overall state of the economy. Atkinson and Morelli (2011) argue that "economic collapses could coincide with other financial crises” (p. 10). If a financial crisis hits the economy, a recession may follow suit. Freeman (2010) shows that income and wealth inequality increased in the US in the context of

\footnotetext{
${ }^{3}$ Piketty (2019), in his sequel to Capitalism in the 21th Century, analyses the interrelationship between inequality and ideology. With a discussion of other conceptualizations, he defines ideology as "a more or less coherent attempt to provide answers to a broad set of questions about the desirable or ideal organization of society" (p. 16, own translation). In his view, the most recent decades have witnessed a transformation of the political cleavages in which the left is dominated increasingly by an intellectual "Brahimian" elite that is at loggerheads with the traditional "merchant right". The observed absence of an egalitarian coalition suggests that the impact of the government ideology on inequality should be limited.
} 
the 2007-2009 recession. On the other hand, Roine et al. (2009), looking at top income shares, claim "that in periods of high growth the rich [(the top percentile)] have benefitted more than proportionately over the entire twentieth century". They argue that this is likely because "the top percentile group has a larger share of their income tied to the actual development of the economy, while the following nine (...) are mainly highly salaried workers but with relatively limited bonus programs, stock options, and other performance related payments” (p. 983). If top earners benefit disproportionately from economic growth, recessions should then lead to decreasing income inequality. All in all, the literature thus suggests a potentially complicated interrelationship between financial crises, recessions and inequality. It follows that the overall state of the economy should be included in the analysis as a control variable.

Relatedly, we control for the occurrence of stock market crashes in our analysis, too. Atkinson and Morelli (2011) show that banking crises are unlikely to occur without a stock market crash following suit, while stock market crashes can also occur on their own. The authors also argue that financial market booms, associated with rising stock market prices, typically benefit the rich whose earnings often depend on the performance of financial markets. It follows that the income of the rich would decrease in the case of a financial market crash. The findings by Kuhn et al. (2020), discussed above, would suggest a similar mechanism with respect to wealth inequality. As the rich have a larger share of their wealth in stock, they would lose in the case of a crash. Considering that stock market crashes thus potentially influence the effect of the financial crises analysed in this paper, we include their occurrence as a control variable.

\section{DATA AND METHOD}

This article tests the four hypotheses on the effects of financial crises on both income and wealth inequality through an unbalanced panel data set that comprises 36 OECD countries during the period from 1970 to 2016. We focus on these states since the impact of crises "at the aggregate level differs strongly between advanced, emerging and developing economies” (Brown, 2013, p. 2). Given that OECD member states are mostly developed and democratic countries with market economies, one can assume that financial crises have similar effects on the inequality in these countries. The period covered is predetermined by data availability. The complete dataset comprises measures of income and wealth inequality, indicators for the occurrence of the four types of financial crises, data on the political orientation of the government with respect to economic policy, as well as data on real GDP per capita and the incidence of stock market crashes. 


\section{Operationalization:}

Inequality measures: In order to proxy income inequality within countries, we use the Gini coefficient as provided by Hammar and Waldenström (2017) and focus on net yearly labour earnings, meaning after taxes and employee social security deductions. The advantage of using net earnings is that we automatically control for taxes and get an impression of the effect of financial crises on the resources that people can dispose of (McGregor, Smith, \& Wills, 2019). Another considerable benefit of the data by Hammar and Waldenström (2017) is that due to their consistent collection—using UBS Prices and Earnings reports and labour market statistics from the International Labour Organization - they are comparable over time and space. A drawback is, however, that the unit of observation is occupations and not individuals. The authors aggregate these units such that they represent the whole working population. Additionally, the data represent urban earnings levels, as they are collected in cities. The authors discuss these limitations extensively and show how they adjust for them, making them a minor complication that does not outweigh the benefits of using the data. One may also consider the fact that the Gini provided by the authors considers labour earnings only a disadvantage since households or individuals may also have additional sources of income, for example through the ownership of assets. Nonetheless, much of our outlined theory suggests an impact of the financial crisis types on income inequality through the labour market. This makes the Gini coefficient calculated based on net annual earnings a good proxy for income inequality for our purposes. ${ }^{4}$

We supplement our analysis of the relationship between income inequality and financial crises by also looking at the effect of the different financial crisis types on the income shares of the top percentile, top decile excluding the top percentile, and all ten deciles of the population (see online appendix section A3). We use data provided by the WID, the World Inequality Database (Alvaredo et al., n.d.). For above-mentioned reasons, we look at post-tax national income which is "the sum of primary incomes over all sectors (private and public), minus taxes”. Primary income is mainly composed of the remuneration of employees, but also includes income resulting from, for example, the ownership of real estate (i.e. rent) and financial assets (i.e. interests and dividends) (Eurostat, 2010; INSEE, 2016). The shares are available for the "equal-split adults" population category, where the income is divided equally among spouses (Alvaredo et al., n.d.). Looking at the groups that Roine et al. (2009) label "the rich" (top 1\%) and the "upper middle class" (top 10\% excluding the top 1\%) when evaluating inequality is in line with much of the literature (Atkinson et al., 2011; Roine et al., 2009). The

\footnotetext{
${ }^{4}$ The data is provided continuously from 1970-2015 in three-year intervals for 35 OECD countries. The missing country is Iceland.
} 
central argument behind looking at top income shares as a proxy for inequality is that top shares affect overall inequality (Atkinson et al., 2011). We add the other deciles to the analysis in order to see who in the population wins or loses if the top earners lose or win. One complication is that the WID post-tax income share data is not limited to labour earnings but covers all primary incomes. Is available only for a subset of OECD countries and only from 1980 onwards for most of these countries. Additionally, the comparability of the results between the two sources might be limited due to the reliance on equal split adults as the population category.

Data on wealth inequality is even harder to come by than data on income inequality. For example, the WID only provides net personal wealth shares for three OECD countries (France, United Kingdom, and United States) and covers different population categories in those cases. We thus resort to the wealth-to-income ratio as a proxy for wealth inequality, also provided by the WID but for a few more countries. The ratio is the quotient resulting from the division of national wealth by national income (Alvaredo et al., n.d.). Fuller, Johnston, and Regan (2020) assert that the ratio serves as a proxy for wealth inequality if a number of conditions are met and argue that these conditions are likely to hold in the case of the thirteen countries in their sample. ${ }^{5}$ We follow Fuller et al. (2020) in using these thirteen countries when analysing the relationship between financial crises and wealth inequality. ${ }^{6}$

Financial crises: Data on financial crisis stems from two sources: Banking and currency crises are taken from Laeven and Valencia (2018), while Reinhart and Rogoff (2011) is the source for inflation crises. Sovereign debt crises combine both datasets.

Table 1 lists the definitions of the four types of financial crises as provided by the authors and augmented by additional information where necessary. The combined dataset contains 91 financial crisis starts, resulting in a total of 243 crisis years. $^{7}$ There are 36 banking crises episodes resulting in 137 banking crisis years; 28 currency crises (both episodes and years); 29 inflation crises episodes resulting in 111 inflation crisis years; and 9 debt crises episodes resulting in 43 debt crises years. Only four out of 36 OECD countries did not experience any crisis episode in the period from 1970 to $2016 .^{8}$

\footnotetext{
5 "Our assertion is that a rising wealth-to-income ratio can alert us to trends in wealth inequality so long as three conditions are met: (1) wealth is more concentrated than income; (2) rising wealth-to-income ratios are not fuelled by wealth accumulation among the poor; and (3) rising wealth-to-income ratios are not fuelled by relatively declining incomes. If these three conditions hold, or can be controlled for, then we can assume that any significant increase in the wealth-to-income ratio also reflects a rise in wealth inequality, and that whatever is driving up the wealth/ income ratio is also responsible for rising wealth inequalities.” (Fuller et al., 2020, p. 302).

${ }^{6}$ The thirteen countries are Australia, Canada, Denmark, France, Germany, Italy, Japan, Netherlands, Norway, Spain, Sweden, United Kingdom, United States.

7 There are 1692 country-year observations in total.

${ }^{8}$ The Online appendix lists the occurrence of financial crises by type and country.
} 
Table 1-Financial Crisis Types

\begin{tabular}{|c|c|}
\hline Type & Definition and Information \\
\hline Banking Crisis & $\begin{array}{l}\text { "[W]e define a banking crisis as an event that meets two conditions: } 1 \text { ) Sig- } \\
\text { nificant signs of financial distress in the banking system (as indicated by } \\
\text { significant bank runs, losses in the banking system, and/or bank liquida- } \\
\text { tions). 2) Significant banking policy intervention measures in response to } \\
\text { significant losses in the banking system" (Laeven \& Valencia, 2018, p. 4). } \\
\text { The authors provide onset and ongoing crisis years, defining the end year } \\
\text { of a crisis as the "year before both real GDP growth and real credit growth } \\
\text { are positive for at least two consecutive years" (p. 21). They truncate the } \\
\text { length of a crisis at five years, however. }\end{array}$ \\
\hline Currency Crisis & $\begin{array}{l}\text { "We define a currency crisis as a "sharp" nominal depreciation of the cur- } \\
\text { rency vis-a-vis the U.S. dollar. We consider two thresholds for a deprecia- } \\
\text { tion to meet this definition: i) a year-on-year depreciation of at least } 30 \text { per- } \\
\text { cent; and ii) of at least } 10 \text { percentage points higher than the rate of depreci- } \\
\text { ation observed in the year before" (Laeven \& Valencia, 2018, p. 9). } \\
\text { The authors only code single crisis years. }\end{array}$ \\
\hline Inflation Crisis & $\begin{array}{l}\text { "[W]e define an inflation crisis using a threshold of } 20 \text { per cent per annum" } \\
\text { (Reinhart \& Rogoff, 2011, p. 1678). } \\
\text { The dataset does not cover the years after } 2010 \text { and nine OECD countries. }\end{array}$ \\
\hline Debt Crisis & $\begin{array}{l}\text { "External debt crises involve outright default on payment of debt obliga- } \\
\text { tions incurred under foreign legal jurisdiction, including nonpayment, repu- } \\
\text { diation, or the restructuring of debt into terms less favorable to the lender } \\
\text { than in the original contract" (Reinhart \& Rogoff, 2011, pp. 1679-1680). } \\
\text { The authors define the final year of a debt crisis as the year in which the } \\
\text { final resolution with the creditors takes place. All of the debt crises coded } \\
\text { by Laeven and Valencia (2018) are also coded by Reinhart and Rogoff. The } \\
\text { only exception is the debt crisis in Greece, 2012, which is a year not covered } \\
\text { by Reinhart and Rogoff. Since Greece exited the final bailout programme } \\
\text { in 2018, we code the years until } 2016 \text { as ongoing crisis years (CFR, n.d.). } \\
\text { Given that Laeven and Valencia code no further debt crises in the countries } \\
\text { and years not covered by Reinhart and Rogoff, information on debt crises } \\
\text { is provided for all years and all countries in our panel despite the debt crisis } \\
\text { definition being based mostly on Reinhart and Rogoff. }\end{array}$ \\
\hline
\end{tabular}

Government ideology: We use the Database of Political Institutions (DPI) 2017 as the source for government ideology (Scartascini, Cruz, \& Keefer, 2018). The DPI provides data on the party orientation of the up to three largest government parties with respect to economic policy. According to the codebook, they code a party as "Right: for parties that are defined as conservative, Christian democratic, or right-wing. Left: for parties that are defined as communist, socialist, social democratic, or left-wing. Center: for parties that are defined as centrist or when 
party position can best be described as centrist (e.g., party advocates strengthening private enterprise in a social-liberal context).” We summarize the party orientation of the three largest government parties in one "government ideology" variable. It is a weighted average of the (up to) three biggest government parties' orientations. The weight is the vote share of each party of the total vote share of the parties. ${ }^{9}$

Control variables: In order to control for the overall state of the economy, we include real GDP per capita in our specification. We follow Roine et al. (2009) in using the Maddison Project Database for data on real GDP per capita (Bolt, Inklaar, de Jong, \& van Zanden, 2018). When controlling for stock market crashes, we resort to the dataset by Reinhart and Rogoff (2011). They follow the Barro-Ursúa definition of stock market crashes as a "cumulative decline of 25 percent or more in real equity prices” (Reinhart \& Rogoff, 2009, p. 250). Since the data is taken from the same dataset as inflation crises, the availability is limited in the same way: there is no information on stock market crashes for the years after 2010 and for nine of the countries covered.

\section{Method:}

We follow Baldacci et al. (2002) and Gokmen and Morin (2019) in using a difference-in-differences (DD) approach as the main empirical strategy in order to measure the effect of the four different types of financial crises on income and wealth inequality. This approach allows us to evaluate effects without choosing a range of predictor variables a priori. Instead, the counterfactual is constructed using a combination of observations from the treated unit but other time periods, and from other units both in the same and other time periods (Imai \& Kim, 2019). ${ }^{10}$

\footnotetext{
${ }^{9}$ For each country and year we calculate: government ideology $=\sum_{j=1}^{N}\left[O_{j} * v_{j}^{*}\right]$ where $v_{j}^{*}=\frac{v_{j}}{\sum_{j=1}^{N} v_{j}}, \sum_{j=1}^{N} v_{j}^{*}=1$ and $N \in\{1,2,3\}$.

$O_{j}$ is the party orientation, $v_{j}$ is the vote share, and $v_{j}^{*}$ is the normalized vote share of party $j . N$ can be 1,2 , or 3 depending on the number of government parties in a country in a year. Since the DPI only provides information on the three largest government parties, the total vote share of government parties (provided in the DPI) is not always equal to the sum of the vote shares of the three largest government parties (used for the calculation of " government ideology").

${ }^{10}$ Other possible methods would have been matching or the synthetical control method. However, both of these rely on choosing or constructing a counterfactual outcome based on a range of predictor variables (Abadie \& Gardeazabal, 2003; Angrist \& Pischke, 2009). As Atkinson and Morelli (2011) claim regarding economic crises and inequality, there is an "interplay between a complex set of mechanisms - economic, social and political" (p. 5). Choosing the appropriate predictors would thus be a difficult exercise and the analysis is likely to be very sensitive to the choice of predictors. Atkinson and Morelli (2011) count the number of crises before and after which inequality rose/was steady/declined and compare total numbers. Morelli (2018) uses an Autoregressive Distributed Lags (ADL) model and estimates impulse response functions to analyse the effect of banking crises on top income shares in the United States. Roine et al. (2009), focussing on various long-run economic determinants of inequality, use first differenced generalized least squares and dynamic first differences using 5-year averages of the data.
} 
While ordinarily applied in a setup with two groups (treatment and control) and two time periods (pre- and post-treatment), this can easily be extended to a setup in which units drop in and out of the treatments status-as is the case for the countries under examination. After running a simple OLS regression of our inequality proxies on the four types of crises to check for correlation between the dependent variable and the independent variables, we apply the DD specification in the main analysis. Eq. (1) summarizes the principal econometric specification:

$$
\text { Inequality }_{c t}=\beta_{1} B C_{c t}+\beta_{2} C C_{c t}+\beta_{3} I C_{c t}+\beta_{4} D C_{c t}+X_{c t}{ }^{\prime} \sigma+\gamma_{c}+\delta_{t}+\varepsilon_{c t} .
$$

Inequality $_{c t}$ is one of the respective inequality proxies (Gini coefficient, income shares, wealth-to-income ratio) in country $c$ in year $t . B C_{c t}, C C_{c t}, I C_{c t}$, and $D C_{c t}$ are dummy variables indicating whether there is a banking crisis, currency crisis, inflation crisis, or debt crisis in country $c$ in year $t$ respectively. $X_{c t}$ is a vector containing the two control variables, real GDP per capita and a dummy variable indicating whether there was a stock market crash in country $c$ in year $t .{ }^{11}$ Further, $\gamma_{c}$ is a full set of country-dummies controlling for time-invariant differences between the countries. The variable captures potential confounders that may influence the development of inequality in an individual country_-for example the political culture or the political system in the country—so long as it does not change over time. $\delta_{t}$ is a full set of timedummies controlling for factors that vary over time and affect all countries. In the present case, such a factor could be a general, OECD-wide downward economic trend. Finally, $\varepsilon_{c t}$ is the error term. Standard errors are clustered at the country level in order to allow for the errors of the same country to be correlated over time. The coefficients on the different types of crises, $\beta_{1}$ to $\beta_{4}$, are the DD estimators. They capture the effect of the respective type of crisis on inequality. The reason for including all four crisis types in the same specification is that it allows us to assess the effect of each type while at the same time controlling for the occurrence of the other types of crises, too. As Reinhart and Rogoff (2009) show: “crises often occur in clusters” (p. xxvi). We present additional regressions including only one crisis type each and including interaction effects between the crisis types in the robustness checks of this paper (see online appendix). Furthermore, an expectable criticism towards including all crisis types in the same specification is that multicollinearity between our independent variables may be a problemespecially considering that debt crises usually occur at the same time as at least one other crisis type (see Table A2 in the online appendix). Bearing this in mind, we study the variance inflation factor (VIF) to check for multicollinearity.

\footnotetext{
${ }^{11}$ Accordingly, $\sigma$ is a vector of the corresponding two coefficients.
} 
Given that the Gini coefficients provided by Hammar and Waldenström (2017) are only available every three years, the time-unit in the analysis of the effect of financial crises on the Gini coefficient are three-year intervals. The four crisis variables and the stock market crash variable are hence not dummies but the share of crisis years of the given crisis type in the three-year period. They can thus take on four values: $0,1 / 3,2 / 3$, or $1 . G D P_{c t}$ is the average real GDP per capita in country $c$ over the three years. ${ }^{12}$

In order for the DD estimator to be treated as the causal effect of the crisis types, the common trends assumption needs to hold: absent the financial crises, the countries' inequality indicators should have developed in the same way on average. As almost all of our units of observation drop in and out of treatment status at different points in time, plotting inequality to assess the validity of this assumption is an unproductive undertaking. However, there is increasing empirical evidence suggesting common trends: income inequality has increased in most OECD countries since the 1980s and the wealth-to-income ratio has grown in rich countries (OECD, 2011; Piketty \& Zucman, 2014). A further challenge is reverse causality, but there is no conclusive evidence that inequality causes financial crises (Atkinson \& Morelli, 2011; Imai \& Kim, 2019). In order to probe the assumption more carefully, we follow Angrist and Pischke (2009) in adding country-specific linear time trends, $\gamma_{2 c} t$, to our specification.

Eq. (2) summarizes the econometric specification that we use to analyse the influence of government ideology on the relationship between financial crises and inequality.

$$
\text { Inequality }_{c t}=\beta_{1} C_{c t}+\beta_{2} \text { Ideolog }_{c t}+\beta_{3} C_{c t} * \text { Ideolog }_{c t}+X_{c t}{ }^{\prime} \sigma+\gamma_{c}+\delta_{t}+\varepsilon_{c t}
$$

$C_{c t}$ is a dummy variable indicating whether there is a financial crisis in country c in year t. We run the regression for each type of crisis individually. We exclude debt crises because there are very few of them but we use a variable we call "any crisis", indicating whether there was any kind of financial crisis in a country in a year. ${ }^{13} C_{c t}$ can thus be "any crisis", a banking crisis, a currency crisis or an inflation crisis. Ideolog $y_{c t}$ is "government ideology" based on the calculations explained above. It is a continuous variable ranging from 0 (Right) to 2 (Left). ${ }^{14}$ The other variables are the same as in Eq. (1). When using the Gini coefficients provided by Hammar and Waldenström (2017), "government ideology" is the mean government ideology in country $c$ over the three years. Here, too,

\footnotetext{
12 In practice, this means that if the Gini coefficient is available for the year 1973, the crisis and control variables refer to the years 1971, 1972, and 1973.

${ }^{13}$ any $C_{c t}=1$ if $B C_{c t}=1$ or $C C_{c t}=1$ or $I C_{c t}=1$ or $D C_{c t}=1$.

${ }^{14}$ In the original DPI dataset, the party orientation variables are categorical with $1=$ Right, $2=$ Centre, $3=$ Left. We recoded these to be $0=$ Right, 1 = Centre, 2 = Left for interpretation purposes. Our government ideology variable is continuous due to it being a weighted average of the party orientations.
} 
we recode the other variables accordingly, as outlined before. We run the regression specified in Eq. (2) individually for each crisis type in order not to take out too much variation and to get a first impression of the interrelationship between inequality, the financial crisis types and government ideology.

\section{RESULTS}

We first present the results of the analysis of the relationship between the different types of financial crises and income inequality, focussing in particular on the Gini coefficient. The sample under consideration covers 26 of the OECD countries and three-year periods from 1971 to 2009. Nine countries drop out of the sample because of the non-availability of data on inflation crises and stock market crashes, one country drops out because Hammar and Waldenström (2017) provide no Gini coefficient for it. ${ }^{15}$ Furthermore, the length of the period under consideration is reduced due to Reinhart and Rogoff (2011) not providing data past 2010.

In Figure 1, we plot the Gini coefficients used for the analysis of the effect of the different types of financial crises on income inequality by country over the period covered in the complete sample. We mark crisis start years by crisis type and highlight ongoing crisis years. A number of observations can be made. Generally, the Gini coefficients vary considerably both within and across countries. It seems that, compared to the other countries, the United States have the most stable Gini coefficient. In the period shown here, most countries' Gini coefficients vary by about ten points on a 0-100 scale throughout the years. Additionally, there is a noticeable drop in the Gini coefficient of many countries in the early 2000s, pointing towards decreasing post-tax income inequality in those countries at that time. Further, eight countries go through inflation crises in the mid-1970s. The Great Recession and the Eurozone crisis are also clearly visible, with fifteen countries experiencing a banking crisis around 2008.

Aside from these observations, examining the relationship between the different types of financial crises and inequality based on the graphs is problematic. Banking crises and inflation crises appear to occur both in times when income inequality is already growing as well as when it is already decreasing. These kind of trends may raise the issue of reverse causality again. Yet, the fact that inequality both increases and decreases before the occurrence of these financial crisis types prevents us from establishing a generalized hypothesis with respect to a possible effect of income inequality on the crises. Making claims regarding debt crisis is also ineffective.

\footnotetext{
${ }^{15}$ The countries dropping out are the Czech Republic, Estonia, Israel, Latvia, Lithuania, Luxembourg, New Zealand, Slovakia, and Slovenia (no information on inflation crisis and stock market crashes) as well as Iceland (no Gini coefficient).
} 
Focussing on currency crises, the graphs suggest a positive relationship between the occurrence of this crisis type and income inequality. A non-negligible pitfall of the graphs is, however, that the crises are marked at the precise onset year while data on the Gini is only available every three years. Thus, while it may appear as though many crises occur in a period in which inequality just changed its trajectory anyway, this may be attributable to the structure of the data. Figure 1 also points to two other difficulties, discussed in more detail in section 6 . First, if the different types of financial crises have an effect on income inequality, then in many cases this effect does not create the impression of being uniform throughout a crisis period. The graph of Japan illustrates the point in question. Inequality declines after the onset of the banking crisis in the late nineties but starts increasing again while the crisis period is still ongoing. The DD specification applied in this paper does not capture these potentially time-varying treatment effects. Second, some of the graphs suggest post-treatment trends, implying that there potentially is an ongoing effect of the crises even after they end according to their respective definitions. Naturally, the DD specification does not capture these potential trends either. Furthermore, the trends imply that the inclusion of the country-specific linear time trends in order to probe the common trends assumption may also have a considerable drawback: the post-treatment trends may get loaded onto the time trends. Consequently, the trends would alter the results more than they should.

Table 2, column 1, shows the results of a simple OLS regression of the four financial crisis types on the Gini coefficient (post-tax earnings). We run this regression in order to assess the correlation between the crises and income inequality. The coefficients suggest a positive relationship between currency and inflation crises and the Gini coefficient, implying that income inequality increases when these types of financial crises occur. No such claims can be made with respect to banking and debt crises. Concerning debt crises, the reader has to remember for the further course of this paper that the only countries going through debt crises in the period under consideration are Chile, Mexico, Poland and Turkey. ${ }^{16}$ Any identified correlation or, henceforth, effect is thus attributable to them. Additionally, almost all debt crisis years additionally occur in parallel to other types of crises (see online appendix Table A2).

\footnotetext{
${ }^{16}$ Greece also goes through a debt crisis starting in 2012 but drops out from the regression analyses because the crisis takes place in years for which no data on inflation crises and stock market crashes is available.
} 
Figure 1-Income Inequality and the Occurrence of Financial Crises (AUS-IRL)
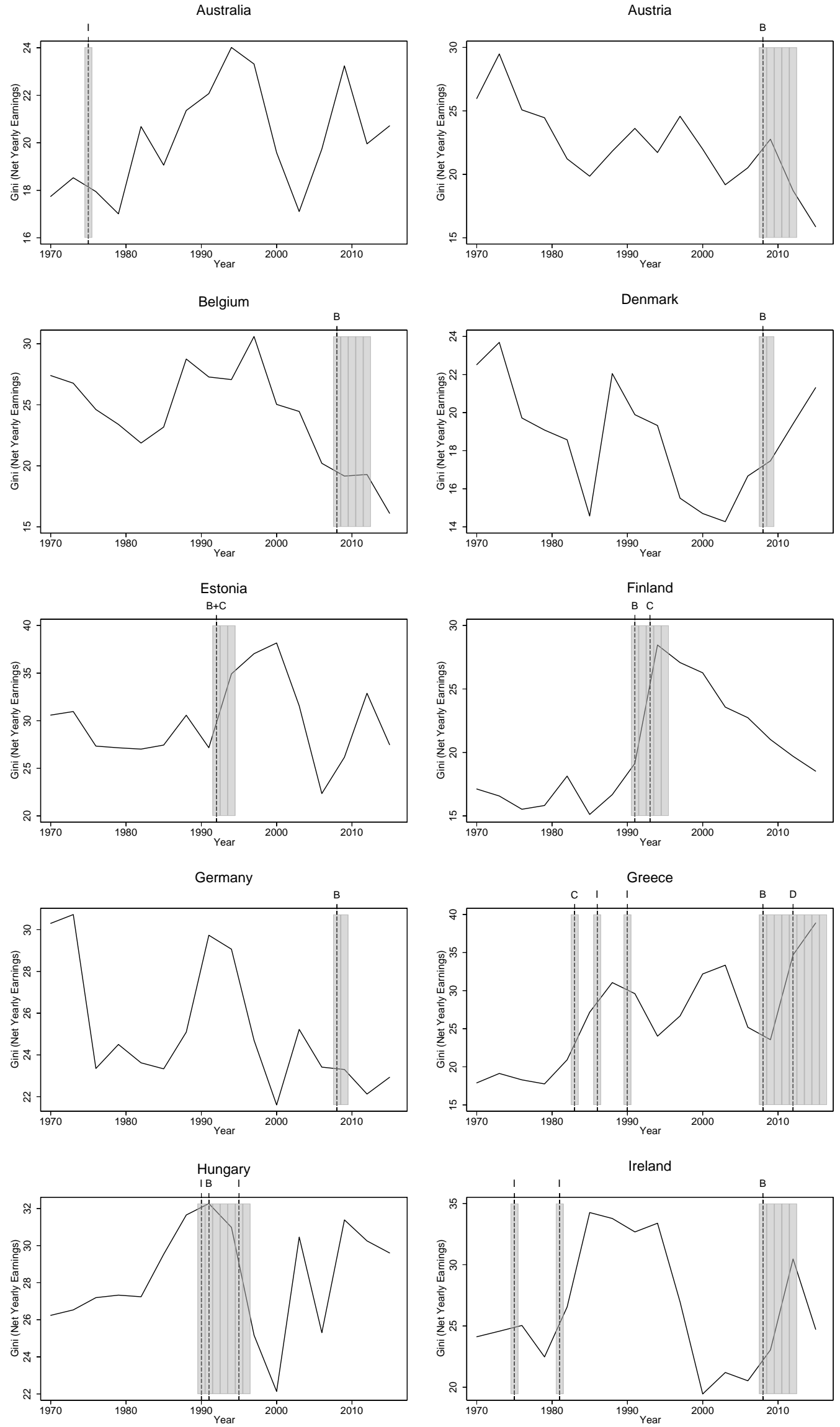
Figure 1-Income Inequality and the Occurrence of Financial Crises (ISR-NOR)
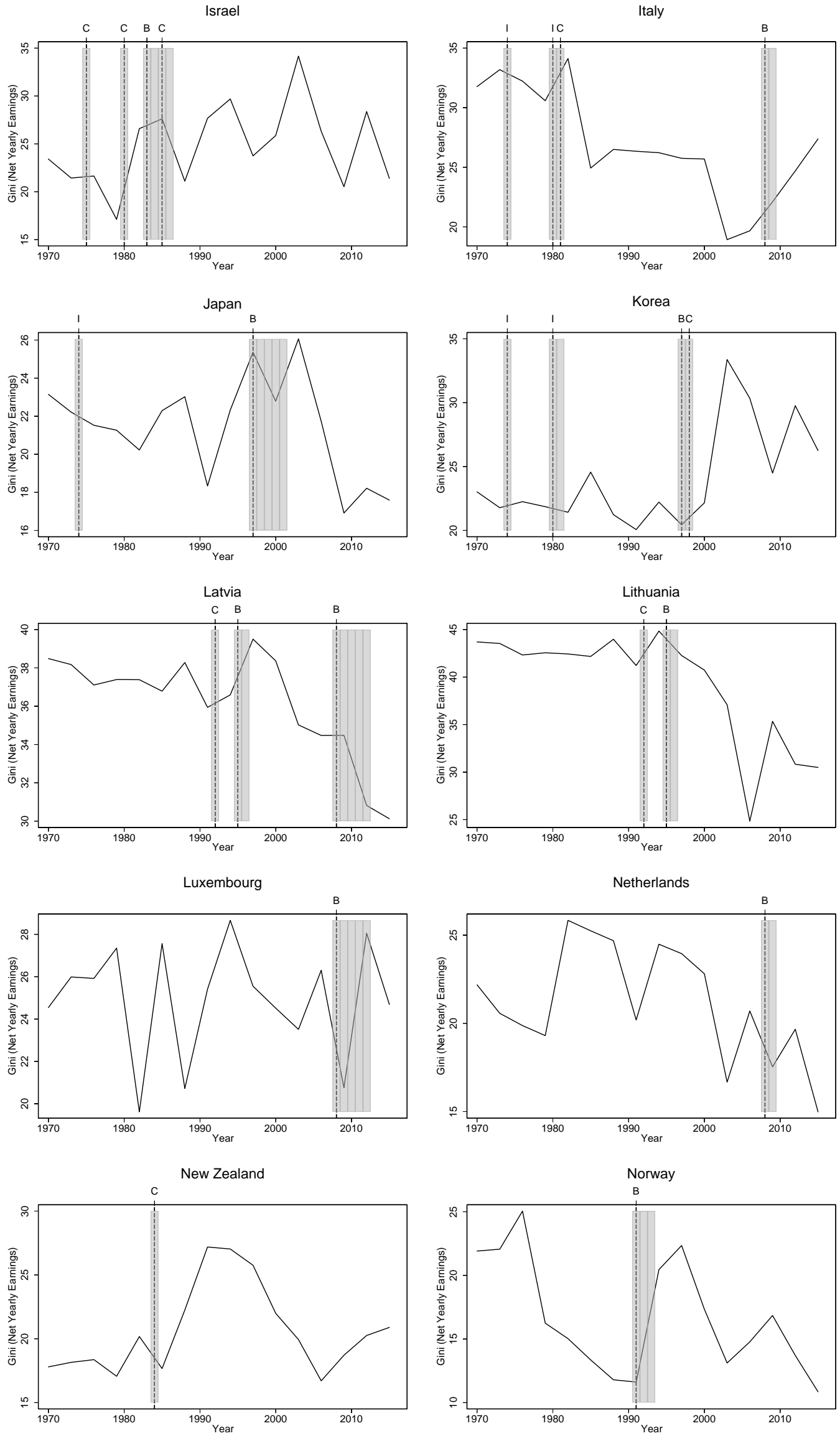
Figure 1-Income Inequality and the Occurrence of Financial Crises

\section{(POL-USA)}
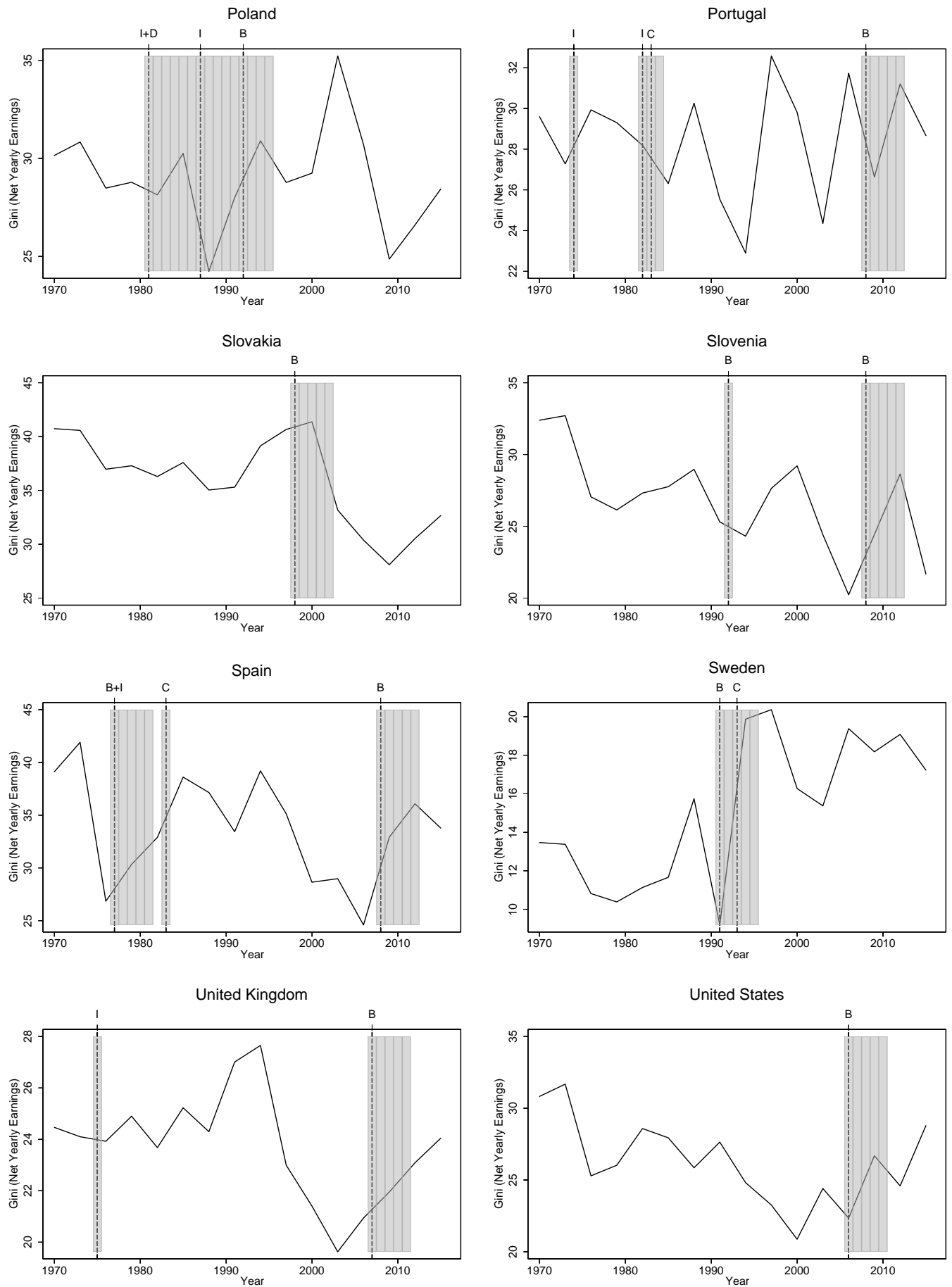

Note: The dashed vertical lines mark the onset year of a crisis. The letters indicate whether the crisis was a banking crisis (B), a currency crisis (C), an inflation crisis (I) or a debt crisis (D). A plus sign (+) between two letters indicates the start of a twin crisis. The shaded areas highlight ongoing crisis years of any crisis type. We do not plot the Gini coefficients of Canada, the Czech Republic, France, and Switzerland due to there being no crises in these countries. Iceland is not plotted due Hammar and Waldenström (2017) not providing data for it. Further, we omit Chile, Mexico, and Turkey since these countries go through such a large quantity of crises that plotting them for the present purpose is a futile exercise. Note further that the y-axis scales are not equalized. 
Table 2-Financial Crisis Types and the Gini Coefficient

\begin{tabular}{|c|c|c|c|c|c|c|}
\hline & \multicolumn{6}{|c|}{ Gini coefficient (post-tax earnings) } \\
\hline & $\begin{array}{l}(1) \\
\text { OLS }\end{array}$ & (2) & (3) & $\begin{array}{l}(4) \\
\text { DD }\end{array}$ & (5) & (6) \\
\hline $\begin{array}{l}\text { Banking } \\
\text { Crisis }\end{array}$ & $\begin{array}{l}-1.127 \\
(1.032)\end{array}$ & & $\begin{array}{l}-0.262 \\
(1.193)\end{array}$ & $\begin{array}{l}-0.313 \\
(1.315)\end{array}$ & $\begin{array}{c}0.621 \\
(1.216)\end{array}$ & $\begin{array}{c}0.539 \\
(1.292)\end{array}$ \\
\hline $\begin{array}{l}\text { Currency } \\
\text { Crisis }\end{array}$ & $\begin{array}{c}14.764^{* *} \\
(6.224)\end{array}$ & & $\begin{array}{l}9.610 * * \\
(3.448)\end{array}$ & $\begin{array}{c}10.183^{* * * *} \\
(3.486)\end{array}$ & $\begin{array}{c}7.175^{* *} \\
(3.136)\end{array}$ & $\begin{array}{l}7.156^{* *} \\
(3.159)\end{array}$ \\
\hline $\begin{array}{l}\text { Inflation } \\
\text { Crisis }\end{array}$ & $\begin{array}{c}8.811^{* *} \\
(3.333)\end{array}$ & & $\begin{array}{c}0.712 \\
(3.296)\end{array}$ & $\begin{array}{c}0.972 \\
(3.359)\end{array}$ & $\begin{array}{l}-0.749 \\
(3.796)\end{array}$ & $\begin{array}{l}-0.352 \\
(3.941)\end{array}$ \\
\hline $\begin{array}{l}\text { Debt } \\
\text { Crisis }\end{array}$ & $\begin{array}{c}-0.995 \\
(6.750)\end{array}$ & & $\begin{array}{l}-5.890 \\
(4.505)\end{array}$ & $\begin{array}{l}-5.402 \\
(4.330)\end{array}$ & $\begin{array}{l}-5.776 \\
(4.521)\end{array}$ & $\begin{array}{l}-5.931 \\
(4.542)\end{array}$ \\
\hline $\begin{array}{l}\text { Any Finan- } \\
\text { cial Crisis }\end{array}$ & & $\begin{array}{c}0.395 \\
(2.133)\end{array}$ & & & & \\
\hline $\begin{array}{l}\text { Real GDP } \\
\text { per capita }\end{array}$ & & $\begin{array}{l}-0.000^{*} \\
(0.000)\end{array}$ & & $\begin{array}{l}-0.000 * \\
(0.000)\end{array}$ & & $\begin{array}{l}-0.000 \\
(0.000)\end{array}$ \\
\hline $\begin{array}{l}\text { Stock Market } \\
\text { Crash }\end{array}$ & & $\begin{array}{c}0.420 \\
(1.479)\end{array}$ & & $\begin{array}{l}-0.013 \\
(1.264)\end{array}$ & & $\begin{array}{l}-0.789 \\
(1.254)\end{array}$ \\
\hline $\begin{array}{l}\text { Country- } \\
\text { specific } \\
\text { trends }\end{array}$ & No & No & No & No & Yes & Yes \\
\hline $\begin{array}{l}\text { Observations } \\
R^{2}\end{array}$ & $\begin{array}{l}338 \\
0.15\end{array}$ & $\begin{array}{l}338 \\
0.09\end{array}$ & $\begin{array}{l}338 \\
0.12\end{array}$ & $\begin{array}{l}338 \\
0.14\end{array}$ & $\begin{array}{l}338 \\
0.35\end{array}$ & $\begin{array}{c}338 \\
0.36\end{array}$ \\
\hline
\end{tabular}

Standard errors in parentheses

$* \mathrm{p}<0.10, * * \mathrm{p}<0.05, * * * \mathrm{p}<0.01$

Note: In column 1, the table reports OLS estimates from a regression of the Gini coefficient on the different types of financial crises. The standard errors are clustered at the country level. In column 2-6, the table report regression DD estimates of the effects of the different types of financial crises on the Gini coefficient. All models include country and three-year period fixed effects. Robust standard errors are clustered at the country level. Crises can take on four values $(0,1 / 3,2 / 3$, or 1$)$ depending on how many years are coded as crisis years within the three-year period in question. The sample used contains the countries and periods for which information on all four crisis types, the control variables and the Gini coefficient is available. The OECD countries missing are the Czech Republic, Estonia, Iceland, Israel, Latvia, Lithuania, Luxembourg, New Zealand, Slovakia, and Slovenia. The three-year periods cover the years 1971 to 2009. 
The other columns of Table 2 display the parametric results of the DD estimation specified in Eq. (1) using the Gini coefficient as the outcome variable. In column 2, instead of regressing the Gini on each of the four crisis types, we use the "any crisis" variable and calculate the share of these "any financial crisis years" over the three-year periods. ${ }^{17}$ We also control for real GDP per capita and stock market crashes. In the remaining four columns, we include each crisis type individually. In column 3, we exclude the control variables. In column 4, we estimate the complete specification. We repeat these two estimations in column 5 and 6 but add the countryspecific linear time trends.

The results from the second model would suggest that financial crises overall do not have an effect on income inequality. The coefficient is small and not statistically significant on any conventional level. The remaining models, differentiating between crisis types, draw a more nuanced picture. The effects of banking crises and inflation crises on inequality are also small and statistically insignificant. Additionally, they are not robust to the inclusion of the countryspecific trends. On the contrary, even the signs of the coefficients change after the inclusion of these trends. This indicates that banking and inflation crises have neither a positive nor a negative relationship with income inequality. The coefficient for currency crises is positive, statistically significant at least at the five percent level and relatively robust to the inclusion of the country-specific trends. These results show that income inequality increases in reaction to currency crises. Considering that the Gini coefficients are only available every three years, the coefficient implies that if there is a currency crisis in a country during the complete three-year interval $\left(C C_{c t}=1\right)$, the Gini increases by somewhere between 7 to 10 points on the $0-100$ Gini scale. The reader needs to remember, however, that currency crises are never coded for longer than one year in the dataset used for this paper (see Table 1) and $C C_{c t}$ is thus never larger than 0.33. The value of the coefficient therefore has to be interpreted with caution. Notwithstanding, if one were to presume that in some cases currency crises last longer than a year, then-assuming no time-varying effects- the coefficient presented above can be considered the lower bound effect of this crisis type. The sign of the coefficients on debt crises is negative. This suggests that income inequality decreases rather than increases in reaction to the occurrence of this crisis type. However, the results are not statistically significant even though this may be attributable to limited statistical power given the rare occurrence of debt crises in our dataset. We extensively discuss the result regarding the effect of debt crises below. Overall, the inclusion of real GDP per capita and stock market crashes as control variables has no considerable impact on the

\footnotetext{
${ }^{17}$ any $C_{c t}=1$ if $B C_{c t}=1$ or $C C_{c t}=1$ or $I C_{c t}=1$ or $D C_{c t}=1$, where $t$ is a three-year interval.
} 
results. Additionally, no VIF value of any crisis type variable passes the conventionally accepted level of 10, indicating that multicollinearity is unproblematic (UCLA-IDRE, n.d.). ${ }^{18}$ In section A3 of the online appendix, we analyse the effects of the four different types of financial crises on income inequality again, this time using the post-tax income share data. We cannot confirm the findings from the analysis using the Gini coefficient as the outcome variable. We come back to this discrepancy in the discussion below.

Table 3 displays the parametric results from the estimation specified in Eq. (2). The results are inconclusive. None of the coefficients is statistically significant on any conventional level and most coefficients, in particular the interaction terms between crisis types and ideology, are not robust to the inclusion of the control variables. The results may suggest that inequality increases in the case of currency crises under left-wing governments. However, in order to draw more reliable conclusions, the analysis would have to be developed further.

\footnotetext{
${ }^{18}$ Given that the VIF values are based on a different code that the main specification, we do not provide them in the output table.
} 
Table 3-Financial Crisis Types, the Gini Coefficient and Ideology

\begin{tabular}{|c|c|c|c|c|c|c|c|c|}
\hline & \multicolumn{8}{|c|}{ Gini coefficient (post-tax earnings) } \\
\hline & (1) & (2) & (3) & (4) & (5) & (6) & (7) & (8) \\
\hline & \multicolumn{8}{|c|}{ DD } \\
\hline Any Crisis & $\begin{array}{l}-0.824 \\
(2.739)\end{array}$ & $\begin{array}{l}-0.050 \\
(3.219)\end{array}$ & & & & & & \\
\hline Banking & & & -0.224 & 1.014 & & & & \\
\hline Crisis & & & $(1.062)$ & (1.207) & & & & \\
\hline Currency & & & & & -4.476 & -0.574 & & \\
\hline Crisis & & & & & (6.563) & $(6.072)$ & & \\
\hline Inflation & & & & & & & -5.406 & -5.354 \\
\hline Crisis & & & & & & & (8.803) & (8.916) \\
\hline Government & 0.540 & 0.817 & 0.482 & 0.772 & 0.359 & 0.487 & 0.677 & 0.692 \\
\hline Ideology & $(0.388)$ & $(0.483)$ & $(0.410)$ & $(0.494)$ & $(0.411)$ & $(0.438)$ & $(0.448)$ & $(0.468)$ \\
\hline Any Crisis & 0.239 & -1.157 & & & & & & \\
\hline X Ideology & (1.840) & (1.917) & & & & & & \\
\hline Banking & & & 0.949 & -0.945 & & & & \\
\hline X Ideology & & & $(1.171)$ & (1.170) & & & & \\
\hline Currency & & & & & 11.802 & 10.784 & & \\
\hline X Ideology & & & & & (8.139) & $(7.974)$ & & \\
\hline Inflation & & & & & & & 0.472 & 0.696 \\
\hline X Ideology & & & & & & & (5.443) & (5.651) \\
\hline Real GDP & & -0.000 & & -0.000 & & -0.000 & & -0.000 \\
\hline per capita & & $(0.000)$ & & $(0.000)$ & & $(0.000)$ & & \\
\hline $\begin{array}{l}\text { Stock Mar- } \\
\text { ket Crash }\end{array}$ & & $\begin{array}{l}-0.283 \\
(1.454)\end{array}$ & & $\begin{array}{l}-0.291 \\
(1.393)\end{array}$ & & $\begin{array}{l}-0.647 \\
(1.339)\end{array}$ & & $\begin{array}{c}-0.372 \\
(1.382)\end{array}$ \\
\hline $\begin{array}{l}\text { Country- } \\
\text { specific } \\
\text { trends }\end{array}$ & No & No & No & No & No & No & No & No \\
\hline $\begin{array}{l}\text { Observa- } \\
\text { tions }\end{array}$ & 316 & 247 & 316 & 247 & 316 & 247 & 247 & 247 \\
\hline$R^{2}$ & 0.13 & 0.12 & 0.13 & 0.12 & 0.16 & 0.17 & 0.13 & 0.14 \\
\hline
\end{tabular}

Standard errors in parentheses

$* \mathrm{p}<0.10, * * \mathrm{p}<0.05, * * * \mathrm{p}<0.01$

Note: The table reports regression DD estimates of the effects of a type of financial crisis on the Gini coefficient, including mean government ideology and an interaction between the crisis type considered and ideology. All models include country and three-year period fixed effects. Robust standard errors are clustered at the country level. Crises can take on four values $(0,1 / 3,2 / 3$, or 1$)$ depending on how many years are coded as crisis years within the three-year period in question. Government ideology is a continuous variable ranging from 0 (right) to 2 (left). The respective samples contain the countries and periods for which information on the on the occurrence of the respective crisis type, government ideology, the control variables (if included) and the Gini coefficient is available. 
In Figure 2, we plot the wealth-to-income ratio and the financial crises in the same way we plotted the Gini coefficient before. Given the limited data availability of the wealth-to-income ratio, the number of crisis episodes is also reduced considerably. Most importantly, none of the countries goes through a debt crisis, leading us to omit this type of financial crisis from the analysis. The thirteen countries in the sample go through eleven banking crisis episodes, six inflation crisis episodes (there is one twin crisis onset combining these two types in Spain), and three currency crisis episodes. Seven of the banking crises are attributable to the Great Recession. Interestingly, the wealth-to-income ratio develops in a $\Lambda$-shaped manner in a majority of the banking crisis episodes. The ratio continues or starts to increase after the onset of a banking crisis but then drops after a year or two. Atkinson and Morelli (2011) discuss a similar pattern in the context of banking crises and income inequality but the logic should hold in the context of wealth inequality, too. The authors attribute the pattern to the typical boom-crash course of a banking crisis: “[a] financial crisis typically occurs after a boom in financial markets, with rising stock market and land prices, which disproportionately benefited the rich. After the crash, it is the rich who have lost most.” (p. 18). Here, the ongoing increase of wealth inequality after the crises have already started suggests that the effect of the boom continues temporarily past the initial crash. This may indicate that wealth inequality is slow to react to shocks. While the observation of the $\Lambda$-shaped pattern is clearly noteworthy and merits further attention, the DD specification that we use in this paper is unlikely to detect an effect of banking crises on the ratio because of this particular shape. Simply eyeballing the development of the ratio in the context of currency and inflation crises leads to no conclusive results.

Table 4 displays the results of an OLS regression and the DD estimation specified in Eq. (1), using the wealth-to-income ratio as the outcome variable, in the same manner the results for the Gini coefficient are presented in Table 2. The coefficients from the OLS regression suggest a positive relationship between banking crises and the wealth-to-income ratio and a negative relationship between currency crises and the ratio. The correlation between banking crises and the proxy for wealth inequality is not in line with the theory, suggesting increasing rather than decreasing inequality in the context of these crises. The results for currency crises are more in line with the theory. The coefficient on inflation crises is statistically insignificant.

Proceeding with the results of the DD estimation, we find no effect of the combined "any financial crisis" variable on the ratio. Additionally, as predicted based on the graphs, no effect can be found for banking crises. For currency and inflation crises, the results suggest a negative effect on the wealth-to-income ratio, implying decreasing wealth inequality in those instances. Following the coefficients, the ratio decreases by around 0.4 units if a currency or an inflation 
crisis occurs. The coefficients are unfortunately not robust to the inclusion of country-specific linear trends. As mentioned above, we discuss these trends and their potential deficiencies in the context of an analysis of the effect of financial crises on inequality in more detail in the next section. Aside from that discussion, limited statistical power may be of overall concern in the investigation of wealth inequality given that the thirteen countries in the sample go through very few financial crises. Regarding multicollinearity, no VIF value of any crisis type variable passes the conventionally accepted level of 10 indicating that, again, multicollinearity is unproblematic.

Table 5 displays the parametric results from the estimation specified in Eq. (2), using wealth inequality as the outcome variable. A first observation is that these results are more robust to the inclusion of the control variables than those in Table 3. In addition, the results suggest that the wealth inequality decreases during currency crises if a government's orientation with respect to economic policy is left rather than right. Model 7 and 8 hint towards decreasing wealth inequality during inflation crises with the trend being less pronounced under left-wing rather than right-wing governments. However, the data and model need refinement before we can make more qualified statements about the interaction between the financial crisis types and government ideology when it comes to the effect of the crisis types on wealth inequality. 

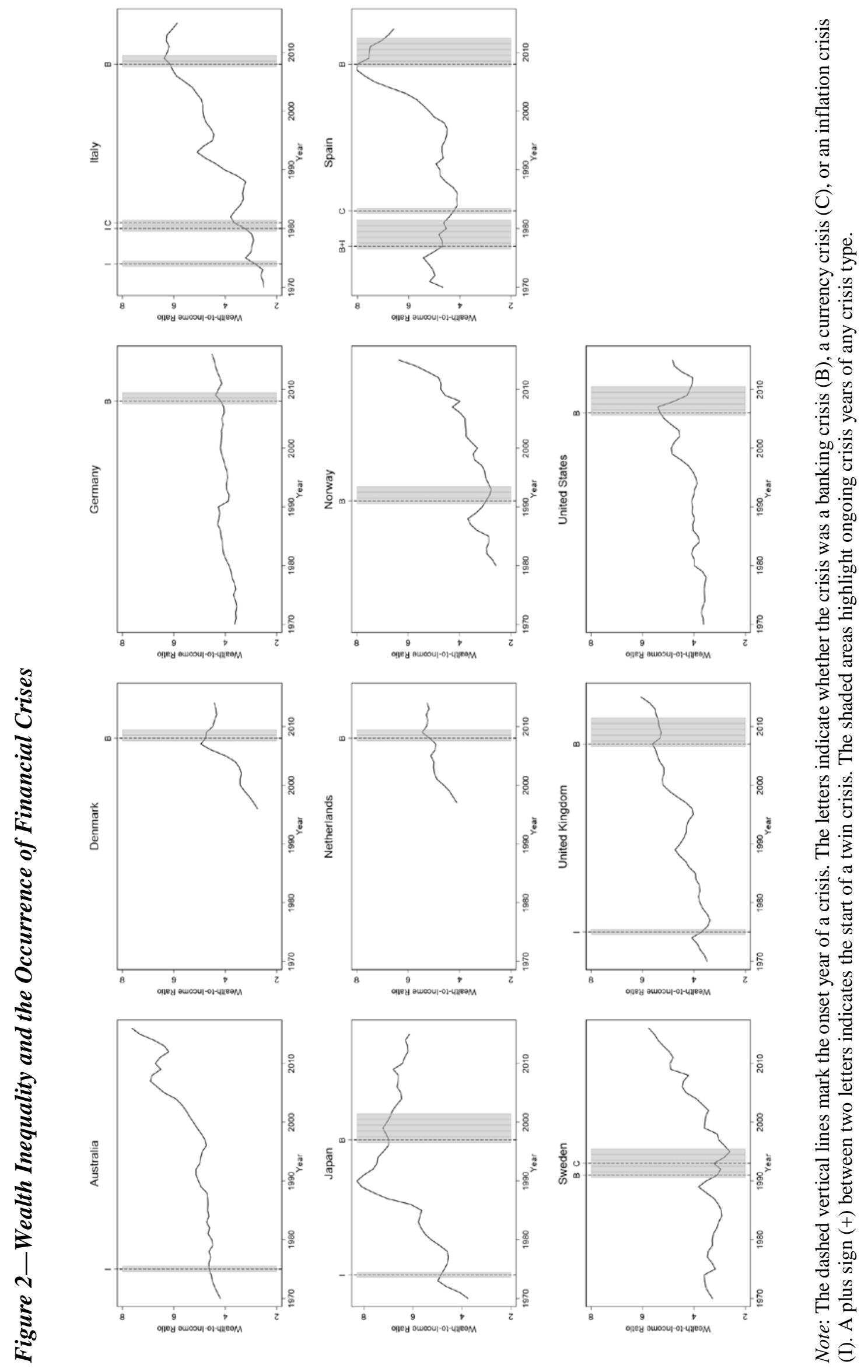

๘ 
Table 4-Financial Crisis Types and the Wealth-to-Income Ratio

\begin{tabular}{|c|c|c|c|c|c|c|}
\hline & \multicolumn{6}{|c|}{ Wealth-to-Income Ratio } \\
\hline & $\begin{array}{c}(1) \\
\text { OLS }\end{array}$ & (2) & (3) & $\begin{array}{l}(4) \\
\text { DD }\end{array}$ & (5) & (6) \\
\hline Banking & $0.800^{* *}$ & & 0.001 & 0.000 & -0.030 & 0.012 \\
\hline Crisis & $(0.331)$ & & $(0.214)$ & $(0.217)$ & $(0.234)$ & $(0.232)$ \\
\hline $\begin{array}{l}\text { Currency } \\
\text { Crisis }\end{array}$ & $\begin{array}{c}-0.837 * * \\
(0.383)\end{array}$ & & $\begin{array}{c}-0.388 * * \\
(0.148)\end{array}$ & $\begin{array}{c}-0.404 * * \\
(0.153)\end{array}$ & $\begin{array}{l}-0.156 \\
(0.218)\end{array}$ & $\begin{array}{l}-0.114 \\
(0.164)\end{array}$ \\
\hline $\begin{array}{l}\text { Inflation } \\
\text { Crisis }\end{array}$ & $\begin{array}{l}-0.416 \\
(0.348)\end{array}$ & & $\begin{array}{c}-0.425 * * * \\
(0.137)\end{array}$ & $\begin{array}{c}-0.421 * * * \\
(0.133)\end{array}$ & $\begin{array}{l}-0.051 \\
(0.089)\end{array}$ & $\begin{array}{l}-0.041 \\
(0.084)\end{array}$ \\
\hline $\begin{array}{l}\text { Any Finan- } \\
\text { cial Crisis }\end{array}$ & & $\begin{array}{l}-0.117 \\
(0.171)\end{array}$ & & & & \\
\hline $\begin{array}{l}\text { Real GDP } \\
\text { per capita }\end{array}$ & & $\begin{array}{c}0.000 \\
(0.000)\end{array}$ & & $\begin{array}{c}0.000 \\
(0.000)\end{array}$ & & $\begin{array}{c}0.000 \\
(0.000)\end{array}$ \\
\hline $\begin{array}{l}\text { Stock Market } \\
\text { Crash }\end{array}$ & & $\begin{array}{c}0.123 \\
(0.132)\end{array}$ & & $\begin{array}{c}0.114 \\
(0.130)\end{array}$ & & $\begin{array}{c}0.133 \\
(0.081)\end{array}$ \\
\hline $\begin{array}{l}\text { Country } \\
\text {-specific } \\
\text { trends }\end{array}$ & No & No & No & No & Yes & Yes \\
\hline $\begin{array}{l}\text { Observations } \\
R^{2}\end{array}$ & $\begin{array}{l}470 \\
0.04\end{array}$ & $\begin{array}{l}468 \\
0.61\end{array}$ & $\begin{array}{l}470 \\
0.61\end{array}$ & $\begin{array}{l}468 \\
0.61\end{array}$ & $\begin{array}{l}470 \\
0.71\end{array}$ & $\begin{array}{l}468 \\
0.73\end{array}$ \\
\hline
\end{tabular}

Standard errors in parentheses

${ }^{*} \mathrm{p}<0.10,{ }^{* *} \mathrm{p}<0.05, * * * \mathrm{p}<0.01$

Note: In column 1, the table reports OLS estimates from a regression of the wealth-to-income ratio on the different types of financial crises. Errors are clustered at the country level. In column 2-6, the table reports regression DD estimates of the effects of the different types of financial crises on the wealth-to-income ratio. All models include country and year fixed effects. Robust standard errors are clustered at the country level. The sample covers Australia, Canada, Denmark, France, Germany, Italy, Japan, Netherlands, Norway, Spain, Sweden, United Kingdom, and the United States. The years for which the ratio is available for these countries can be taken from Appendix Table A1. 
Table 5-Financial Crisis Types, the Wealth-to-Income Ratio and Ideology

\begin{tabular}{|c|c|c|c|c|c|c|c|c|}
\hline & \multicolumn{8}{|c|}{ Wealth-to-Income Ratio } \\
\hline & (1) & (2) & (3) & (4) & (5) & (6) & (7) & (8) \\
\hline & \multicolumn{8}{|c|}{$\mathrm{DD}$} \\
\hline Any Crisis & $\begin{array}{l}-0.116 \\
(0.239)\end{array}$ & $\begin{array}{c}-0.218 \\
(0.212)\end{array}$ & & & & & & \\
\hline Banking & & & -0.099 & -0.206 & & & & \\
\hline Crisis & & & $(0.232)$ & $(0.207)$ & & & & \\
\hline Currency & & & & & 0.033 & 0.053 & & \\
\hline Crisis & & & & & $(0.192)$ & $(0.175)$ & & \\
\hline Inflation & & & & & & & $-0.985 * *$ & $-0.797 *$ \\
\hline Crisis & & & & & & & $(0.345)$ & $(0.429)$ \\
\hline Government & -0.027 & -0.035 & -0.030 & -0.039 & -0.023 & -0.030 & -0.029 & -0.030 \\
\hline Ideology & $(0.031)$ & $(0.039)$ & $(0.032)$ & $(0.039)$ & $(0.027)$ & $(0.033)$ & $(0.033)$ & $(0.033)$ \\
\hline Any Crisis & 0.051 & 0.073 & & & & & & \\
\hline X Ideology & $(0.225)$ & $(0.208)$ & & & & & & \\
\hline Banking & & & 0.100 & 0.127 & & & & \\
\hline X Ideology & & & $(0.263)$ & $(0.252)$ & & & & \\
\hline Currency & & & & & $-0.320^{*}$ & $-0.339 * *$ & & \\
\hline X Ideology & & & & & $(0.162)$ & $(0.140)$ & & \\
\hline Inflation & & & & & & & 0.352 & 0.246 \\
\hline X Ideology & & & & & & & $(0.204)$ & $(0.241)$ \\
\hline Real GDP & & -0.000 & & -0.000 & & -0.000 & & -0.000 \\
\hline per capita & & & & & & & & $(0.000)$ \\
\hline $\begin{array}{l}\text { Stock Mar- } \\
\text { ket Crash }\end{array}$ & & $\begin{array}{c}0.173 \\
(0.126)\end{array}$ & & $\begin{array}{c}0.168 \\
(0.126)\end{array}$ & & $\begin{array}{c}0.155 \\
(0.124)\end{array}$ & & $\begin{array}{c}0.144 \\
(0.129)\end{array}$ \\
\hline $\begin{array}{l}\text { Country- } \\
\text { specific } \\
\text { trends }\end{array}$ & No & No & No & No & No & No & No & No \\
\hline $\begin{array}{l}\text { Observa- } \\
\text { tions }\end{array}$ & 420 & 383 & 420 & 383 & 420 & 383 & 385 & 383 \\
\hline$R^{2}$ & 0.70 & 0.66 & 0.70 & 0.66 & 0.70 & 0.66 & 0.66 & 0.66 \\
\hline
\end{tabular}

Standard errors in parentheses

$* \mathrm{p}<0.10, * * \mathrm{p}<0.05, * * * \mathrm{p}<0.01$

Note: The table reports regression DD estimates of the effects of a type of financial crisis on the wealth-to-income ratio, including government ideology and an interaction between the crisis type considered and ideology. All models include country and year fixed effects. Robust standard errors are clustered at the country level. Government ideology is a continuous variable ranging from 0 (right) to 2 (left). The sample covers Australia, Canada, Denmark, France, Germany, Italy, Japan, Netherlands, Norway, Spain, Sweden, United Kingdom, and the United States and the years for which the ratio as well as information on the occurrence of the respective crisis type, government ideology, and the control variables (if included) is available. 


\section{DISCUSSION}

We now proceed with the discussion of the parametric results. Based on the coefficients from the estimations above, we reject hypothesis $H 1$. There is no evidence that banking crises decrease income inequality or wealth inequality. The evidence for the effect of banking crises on inequality, so far inconclusive in the literature, thus remains so. We can confirm hypothesis $H 2$. Currency crises increase income inequality and the evidence suggests that they decrease wealth inequality to some extent. These findings are in line with the theory and much of the literature, outlined in section II of this paper. While we do not test for the mechanisms through which currency crises affect inequality explicitly, the results indicate that low-wage workers' earnings deteriorate comparatively more in the context of these crises, whereas changes in the value of assets affect the wealth of the richer parts of society more. We reject the first part of hypothesis H3. Based on our results, there is no evidence that inflation crises increase income inequality and, accordingly, that they penalize the poor disproportionately. The findings concerning inflation crises and wealth inequality suggest a negative effect of the former on the latter and are thus in line with those for the effect of currency crises on wealth inequality. Consequently, we can confirm the second part of hypothesis $H 3$ to some extent. Finally, our results hint towards a negative effect of sovereign debt crises on income inequality. This would reject hypothesis H4. However, the results are statistically insignificant. Additionally, keeping in mind that only Chile, Mexico, Poland and Turkey go through debt crises between 1971 and 2009, the extent to which this coefficient is a reliable estimate for the effect of debt crises on income inequality in other countries is questionable. The simultaneity of debt crises and other crisis types casts further doubt on this result. Even though we control for the occurrence of other crisis types in our specification, it is not guaranteed that a detected effect of debt crises can really be ascribed to this particular type. We briefly return to the discussion of the effect of debt crises on income inequality in the section on robustness checks in the online appendix.

While we have continually discussed some limitations of our model and results throughout the preceding sections, we go into a little more detail in here. As the regression tables show, many of our parametric results are not robust to the inclusion of country-specific time trends. Even though the inclusion of these trends is widely applied to probe the common trends assumption in a DD model, it also comes with some caveats. With country-specific time trends, the identification of an effect is based on whether a type of financial crisis leads to deviations from prior country-specific trends. However, "state-specific trends may pick up the effects of a [treatment] and not just preexisting trends” (Wolfers, 2006). More specifically, the trends may capture an omitted variable bias. If there exist omitted factors that vary within a country over 
time and that influence inequality and are correlated with the financial crisis types, then they bias the estimated effects. Putting this differently, omitting these factors biases the coefficient if there is a systematic relationship between the trends in inequality and the occurrence of the crisis types. The idea is that the inclusion of the country-specific trends captures these factors (Wolfers, 2006). Figure 1 and Figure 2 may indeed suggest the existence of such factors and thus an endogeneity problem with respect to the occurrence of the financial crisis types and inequality. However, the fact that there appear to be both decreasing as well as increasing trends in inequality both across and within countries before the different crisis types occur, puts into doubt the systematicness of the relationship. Wolfers (2006) shows that aside from potentially capturing an omitted variable bias, the country-specific trends also capture post-treatment trends. Financial crises may have long-run effects on inequality that continue beyond the official end of a crisis episode. Figure 1 and Figure 2 certainly do not exclude this possibility. The effect of the time trends in our model thus has to be interpreted with due caution. Notwithstanding, the impact of the inclusion points towards the need of applying a more sensitive identification strategy when assessing the relationship between different types of financial crises and inequality.

The DD model also does not allow for time-varying treatment effects. For example, there may be stronger effects at the onset of a crisis than during the ongoing years of the same crisis. We presume that this is an issue given that, for example, political measures introduced after the onset of a crisis to limit its consequences can be expected to take effect only after a few years. On the other hand, the effects of financial crises could of course also set in with delay, for example if inequality was to react slowly to changes in the economy or the financial sector. Additionally, the DD model does not control for the length of a crisis, which may have an impact on the strength of the effect of a crisis on inequality, too- especially when considering the potential existence of the post-treatment trends discussed above. In a similar vein, our model does not take into account a potential interdependency of the four financial crisis types. While around half of the countries in our sample go through only one financial crisis in the period covered or the crises occur with a considerable time gap between them, the other half go through multiple, sometimes overlapping crisis episodes. It is possible that under certain circumstances, the crisis types cause each other, leading to an even more complicated relationship with inequality. Ensuing research should take care of analysing whether these factors matter.

Linked to the discussion of potential endogeneity, the country-specific linear time trends, and the time-varying treatment effects, is the drawback of having the financial crisis types coded as binary variables. The definitions of the crises types by Laeven and Valencia (2018) 
and Reinhart and Rogoff (2011) are fairly strict, demanding significant distress — whether it be in the context of banks, currency, inflation or sovereign debt—before a year is coded as a crisis year. Events such as bank runs and banking policy interventions can indeed be sudden and their exact date accurately identifiable. However, especially currency depreciations and inflation rates can deteriorate for a long time before their levels actually reach the thresholds defined by the authors. It is difficult to argue why inequality should react to a currency depreciation of 30 percent or an inflation rate of 20 percent per annum but not of 25 or 15 percent respectively. Currency depreciations and inflation rates may thus induce pre-crisis trends in inequality that can already be attributed to the imminent currency or inflation crisis. Evidently, the binary crisis variables and the DD model do not allow us to capture this kind of situation.

Finally, the discrepancy between the results of the regressions using the Gini coefficient and those using the income shares merits some attention. A number of factors can explain this discrepancy. First, the Gini has been criticised for being insensitive to changes in the top and the bottom of the distribution and may thus not capture the marginal losses of the top earners following currency crises identified by the regression using the top income shares (Cobham \& Sumner, 2014). However, Table A4b in the online appendix suggests that the rich's losses benefitted the lowest six deciles equally which the Gini coefficient should then capture. Hence, the results still contradict the effects of currency crises identified by the specification using the Gini coefficient as the outcome variable. What is more likely is that the effects differ due to the Gini coefficient and the shares recording different types of income: urban labour earnings only in the case of the Gini vis-à-vis all primary incomes in the case of the shares. We cannot rule out that both the labour earnings of the poor and the primary incomes of the rich-especially if the latter depend considerably on the income from the ownership of property or financial assetsare susceptible to currency crises. As we show in the robustness checks section in the online appendix (section A4), the discrepancy is not due to the analysis of the effect on the shares using a smaller sample. We re-run the main specification with the Gini coefficient serving as the outcome variable but using a restricted sample, excluding all those countries and years that we also had to exclude when assessing the effect on the income shares (see online appendix Table A9).

In section A4, we conduct four robustness checks in total. Aside from the one just explained, we also run the main econometric specification for each crisis type individually. We then repeat our main specification, but instead of using variables capturing all crisis years of each crisis type, we use variables only capturing the onset year of each crisis type. Finally, we rerun the main specification using the Gini coefficient as the outcome variable but additionally include 
interaction terms for twin crises. We explain the purpose and implementation of each robustness check extensively.

\section{Conclusion}

In this paper we pose the research question: does the effect of financial crises on income and wealth inequality differ depending on the type of crisis? Using a difference-in-differences specification strategy and an unbalanced panel covering the OECD countries and the period 1970 to 2016, we show that the effect does indeed differ between crisis types. For banking crises and the inflation crises, no effect on income inequality, measured by a Gini coefficient based on yearly net labour earnings, is discernible. Currency crises increase income inequality. Running the analysis with income shares as the dependent variable does not confirm this relationship. We explain this differential outcome by pointing towards the diverging definitions of "income" considered for the Gini coefficient and the shares. The evidence concerning debt crises depends a lot on the model specification and a number of limitations make it difficult to draw generalizable conclusions. Suggestive evidence indicates that currency and inflation crises have a decreasing effect on wealth inequality, measured by the wealth-to-income ratio in a country.

Aside from the just listed results of the baseline econometric specification, our paper is relevant for the future research on financial crises and inequality as our discussion and robustness checks highlight a number of aspects the research needs to take into consideration. Future research should consider pre- and post-financial crisis trends carefully. It also has to allow and test for possible time-varying treatment effects throughout a crisis episode. The $\Lambda$-shaped pattern of the inequality trajectory, especially during banking crises, deserves particular attention, as well as the possibility that in some cases the reaction of inequality to different types of financial crises could be delayed. Throughout the paper, we point towards the need to apply an identification strategy that is more sensitive to all or at least some of the aspects just listed. An error correction model such as the one used by Fuller et al. (2020) may be a good next step.

Furthermore, in this study we focus on the total effect of the types of financial crises on inequality rather than on evaluating the individual channels through which the effect runs. We outline many of these potential channels in the theory section. For example, in order not to burst the scope of this paper, we have disregarded the possible effect that national policies or international bailouts, for example through the IMF in the case of debt crises, could have. This is a promising path for future research. As Bohoslavsky (2016) argues, it is likely that the effects that the different types of financial crises have on income and wealth inequality, are at least partially channelled through this mechanism. Of course, we partly control for national fiscal 
policies when assessing income inequality considering that we use post-tax income measures. However, austerity policies such as government spending cuts, adopted following conditional IMF bailouts or unilaterally in reaction to a financial crisis, are an example of channels deserving further attention.

Finally, given the interesting results with respect to the effect of the different types of financial crises on the post-tax labour earnings Gini coefficient provided by Hammar and Waldenström (2017), we suggest conducting further research using their dataset. Much of the logic concerning how the crisis types affect inequality is based on an effect via the labour market. For example, the theory suggests that at least currency and inflation crises affect the importand the export-oriented sectors differently. The authors provide Gini coefficients by different occupations. Researchers should capitalize on this in order to assess the relationship between financial crisis types and inequality more nuancedly. 


\section{BIBLIOGRAPHY}

Abadie, A., \& Gardeazabal, J. (2003). The Economic Costs of Conflict: A Case Study of the Basque Country. The American Economic Review, 93(1), 113-132. Retrieved from https://pubs.aeaweb.org/doi/pdfplus/10.1257/000282803321455188.

Alesina, A., \& Drazen, A. (1991). Why are Stabilizations Delayed? The American Economic Review, 81(5), 1170-1188. Retrieved from http://www.jstor.org/stable/2006912.

Alesina, A., Favero, C. A., \& Giavazzi, F. (2018). Climbing Out of Debt. Finance \& Development, 55(1), 6-11. Retrieved from https://www.imf.org/external/pubs/ft/fandd/2018/03/alesina.htm.

Alvaredo, F., Atkinson, A. B., Chancel, L., Piketty, T., Saez, E., \& Zucman, G. (n.d.). World Inequality Database. Retrieved from: https://wid.world/.

Angrist, J. D., \& Pischke, J.-S. (2009). Mostly Harmless Econometrics. Princeton: Princeton University Press.

Atkinson, A. B., \& Morelli, S. (2011). Economic Crises and Inequality. Human Development Research Paper. Retrieved from http://hdr.undp.org/sites/default/files/hdrp_2011_06.pdf.

Atkinson, A. B., Piketty, T., \& Saez, E. (2011). Top Incomes in the Long Run of History. Journal of Economic Literature, 49(1), 3-71. Retrieved from https://eml.berkeley.edu/ saez/atkinson-piketty-saezJEL10.pdf.

Baldacci, E., Mello, L. d., \& Inchauste, G. (2002). Financial Crises, Poverty, and Income Distribution. WP/02/4. Retrieved from https://papers.ssrn.com/sol3/papers.cfm?abstract_id=879312.

Bohoslavsky, J. P. (2016). Economic Inequality, Debt Crises and Human Rights. Yale Journal of International Law, 41, Special Edition on Sovereign Debt. Retrieved from http://www.yjil.yale.edu/volume-41-special-edition/.

Bolt, J., Inklaar, R., de Jong, H., \& van Zanden, J. L. (2018). Maddison Project Database, Version 2018. Retrieved from:

https://www.rug.nl/ggdc/historicaldevelopment/maddison/releases/maddison-projectdatabase-2018.

Bordo, M., Eichengreen, B., Klingebiel, D., Martinez-Peria, M. S., \& Rose, A. K. (2001). Is the Crisis Problem Growing More Severe? Economic Policy, 16(32), 51-82. Retrieved from https://www.jstor.org/stable/3601034?pq-

origsite=summon\&seq=1\#metadata_info_tab_contents.

Brown, M. (2013). The Transmission of Banking Crises to Households: Lessons from the 2008-2011 Crises in the ECA Region. Retrieved from https://openknowledge.worldbank.org/handle/10986/16322.

CFR. (n.d.). Greece's Debt 1974 - 2018. Council on Foreign Relations. Retrieved from https://www.cfr.org/timeline/greeces-debt-crisis-timeline.

Cobham, A., \& Sumner, A. (2014). Is Inequality All About the Tails?: The Palma Measure of Income Inequality. Significance, 11(1), 10-13. Retrieved from https://rss.onlinelibrary.wiley.com/doi/full/10.1111/j.1740-9713.2014.00718.x.

Eurostat. (2010). Eurostat Regional Yearbook 2010 - Chapter 5: Household Accounts. Retrieved from https://ec.europa.eu/eurostat/documents/3217494/5725281/KS-HA-10001-05-EN.PDF/71e5a187-095e-4283-a900-3cffdc9908b6.

Freeman, R. B. (2010). It's Finacialization. International Labour Review, 149(2), 163-183. Retrieved from https://onlinelibrary.wiley.com/doi/abs/10.1111/j.1564913X.2010.00082.

Fuller, G. W., Johnston, A., \& Regan, A. (2020). Housing Prices and Wealth Inequality in Western Europe. West European Politics, 43(2), 297-320. Retrieved from https://www.tandfonline.com/doi/full/10.1080/01402382.2018.1561054. 
Galbraith, J. K., \& Jiaqing, L. (1999). Inequality and Financial Crises: Some Early Findings. UTIP Working Paper Number 9. Retrieved from https://utip.lbj.utexas.edu/papers/utip_09enc.pdf.

Genovese, F., Schneider, G., \& Wassmann, P. (2016). The Eurotower Strikes Back: Crises, Adjustments, and Europe's Austerity Protests. Comparative Political Studies, 49(7), 939-967. Retrieved from https://doi.org/10.1177/0010414015626444.

Gokmen, G., \& Morin, A. (2019). Inequality in the Aftermath of Financial Crises: Some Empirical Evidence. Applied Economics Letters, 26(19), 1558-1562. Retrieved from https://www.tandfonline.com/doi/full/10.1080/13504851.2019.1584366.

Hammar, O., \& Waldenström, D. (2017). Global Earnings Inequality, 1970-2018. Economic Journal, forthcoming. Retrieved from https://www.econstor.eu/bitstream/10419/197684/1/88741334X.pdf and http://www.uueconomics.se/danielw/Data.htm.

Hibbs, D. A. (1977). Political Parties and Macroeconomic Policy. The American Political Science Review, 71(4), 1467-1487. Retrieved from https://www.jstor.org/stable/pdf/1961490.pdf.

Honohan, P. (2005). Banking Sector Crises and Inequality. Retrieved from http://documents.worldbank.org/curated/en/471191468319747826/Banking-sectorcrises-and-inequality.

Huber, E., Huo, J. J., \& Stephens, J. D. (2019). Power, Policy, and Top Income Shares. SocioEconomic Review, 17(2), 231-253. Retrieved from https://academic.oup.com/ser/article/17/2/231/4096441?rss=1.

Imai, K., \& Kim, I. S. (2019). On the Use of Two-way Fixed Effects Regression Models for Causal Inference with Panel Data. Retrieved from https://imai.fas.harvard.edu/research/twoway.html.

INSEE. (2016). Primary Income. Retrieved from https://www.insee.fr/en/metadonnees/definition/c1196.

Keynes, J. M. (1936). The General Theory of Employment, Interest, and Money. London: Macmillan.

Kuhn, M., Schularick, M., \& Steins, U. (2020). Income and Wealth Inequality in America,1949-2016. Journal of Political Economy, 128(9), 3469-3519. Retrieved from https://www.journals.uchicago.edu/doi/pdf/10.1086/708815.

Laeven, L., \& Valencia, F. (2018). Systemic Banking Crises Revisited. WP/18/206. Retrieved from https://www.imf.org/en/Publications/WP/Issues/2018/09/14/Systemic-BankingCrises-Revisited-46232.

Limberg, J. (2019). ‘Tax the Rich'? The Financial Crisis, Fiscal Fairness, and Progressive Income Taxation. European political science review, 11(3), 319-336. Retrieved from https://www.cambridge.org/core/journals/european-political-sciencereview/article/tax-the-rich-the-financial-crisis-fiscal-fairness-and-progressive-incometaxation/902BFE19A40A36AB40BD99B3BF5A80EE.

Lopez, H. (2003). Macroeconomics and Inequality. Working Paper 37572. Retrieved from http://documents.worldbank.org/curated/en/292721468319775386/Macroeconomicsand-inequality.

McGregor, T., Smith, B., \& Wills, S. (2019). Measuring Inequality. OXFORD REVIEW OF ECONOMIC POLICY, 35(3), 368-395. Retrieved from https://academic.oup.com/oxrep/article/35/3/368/5531388.

Morelli, S. (2018). Banking Crises in the US: the Response of Top Income Shares in a Historical Perspective. The Journal of Economic Inequality, 16(2), 257-294. doi:10.1007/s10888-018-9387-9

Nordhaus, W. D. (1975). The Political Business Cycle. The Review of economic studies, 42(2), 169-190. Retrieved from 
https://www.jstor.org/stable/pdf/2296528.pdf?refreqid=excelsior\%3A4ddb821313a72 cc0476b0a53b3a62725.

OECD. (2011). An Overview of Growing Income Inequalities in OECD Countries: Main Findings. In (pp. 21-45). Paris: OECD Publishing.

Piketty, T. (2019). Capital et Idéologie. Paris: Éditions du Seuil

Piketty, T., \& Saez, E. (2003). Income Inequality in the United States, 1913-1998. The Quarterly Journal of Economics, 118(1), 1-39. Retrieved from https://eml.berkeley.edu/ saez/pikettyqje.pdf.

Piketty, T., \& Saez, E. (2013). Top Incomes and the Great Recession: Recent Evolutions and Policy Implications. IMF Economic Review, 61(3), 456-478. Retrieved from http://www.jstor.org/stable/43297798.

Piketty, T., \& Zucman, G. (2014). Capital is Back: Wealth-Income Ratios in Rich Countries 1700-2010. Quarterly journal of economics, 129(3), 1255-1255. Retrieved from http://gabriel-zucman.eu/files/PikettyZucman2014QJE.pdf.

Reinhart, C. M., \& Rogoff, K. S. (2009). This Time Is Different: Eight Centuries of Financial Folly. Princeton: Princeton University Press.

Reinhart, C. M., \& Rogoff, K. S. (2011). From Financial Crash to Debt Crisis. The American Economic Review, 101(5), 1676-1706. Retrieved from https://www.aeaweb.org/articles?id=10.1257/aer.101.5.1676.

Roine, J., Vlachos, J., \& Waldenström, D. (2009). The Long-run Determinants of Inequality: What Can We Learn From Top Income Data? Journal of Public Economics, 93(7-8), 974-988. Retrieved from https://www.sciencedirect.com/science/article/pii/S0047272709000383.

Scartascini, C., Cruz, C., \& Keefer, P. (2018). The Database of Political Institutions 2017 (DPI2017). Washington, DC: Inter-American Development Bank. Retrieved from https://publications.iadb.org/en/database-political-institutions-2017-dpi2017.

Scheve, K., \& Stasavage, D. (2009). Institutions, Partisanship, and Inequality in the Long Run. World Politics, 61(2), 215-253. Retrieved from https://muse.jhu.edu/article/262178.

Sinn, H.-W. (2010). Kasino-Kapitalismus: Wie es zur Finanzkrise kam, und was jetzt zu tun ist. Berlin: Ullstein.

Strange, S. (1986). Casino Capitalism. Oxford: Blackwell.

UCLA-IDRE. (n.d.). Regression with Stata Chapter 2 - Regression Diagnostics. Retrieved from https://stats.idre.ucla.edu/stata/webbooks/reg/chapter2/statawebbooksregressionwith-statachapter-2-regression-diagnostics/.

Vacas-Soriano, C., \& Fernández-Macías, E. (2018). Income Inequality in the Great Recession from an EU-wide Perspective. CESifo Forum, 19(2), 9-18. Retrieved from https://www.ifo.de/DocDL/CESifo-Forum-2018-2-vacas-fernandezincome\%20inequality-june.pdf.

Wolfers, J. (2006). Did Unilateral Divorce Laws Raise Divorce Rates? A Reconciliation and New Results. The American Economic Review, 96(5), 1802-1820. Retrieved from https://www.jstor.org/stable/30034996?pqorigsite=summon\&seq=1\#metadata_info_tab_contents. 
“CASINO CAPITALISM? THE IMPACT OF FINANCIAL CRISES ON INEQUALITY, 1970 TO 2016” ONLINE APPENDIX

\section{A1. DATA AVAILABILITY}

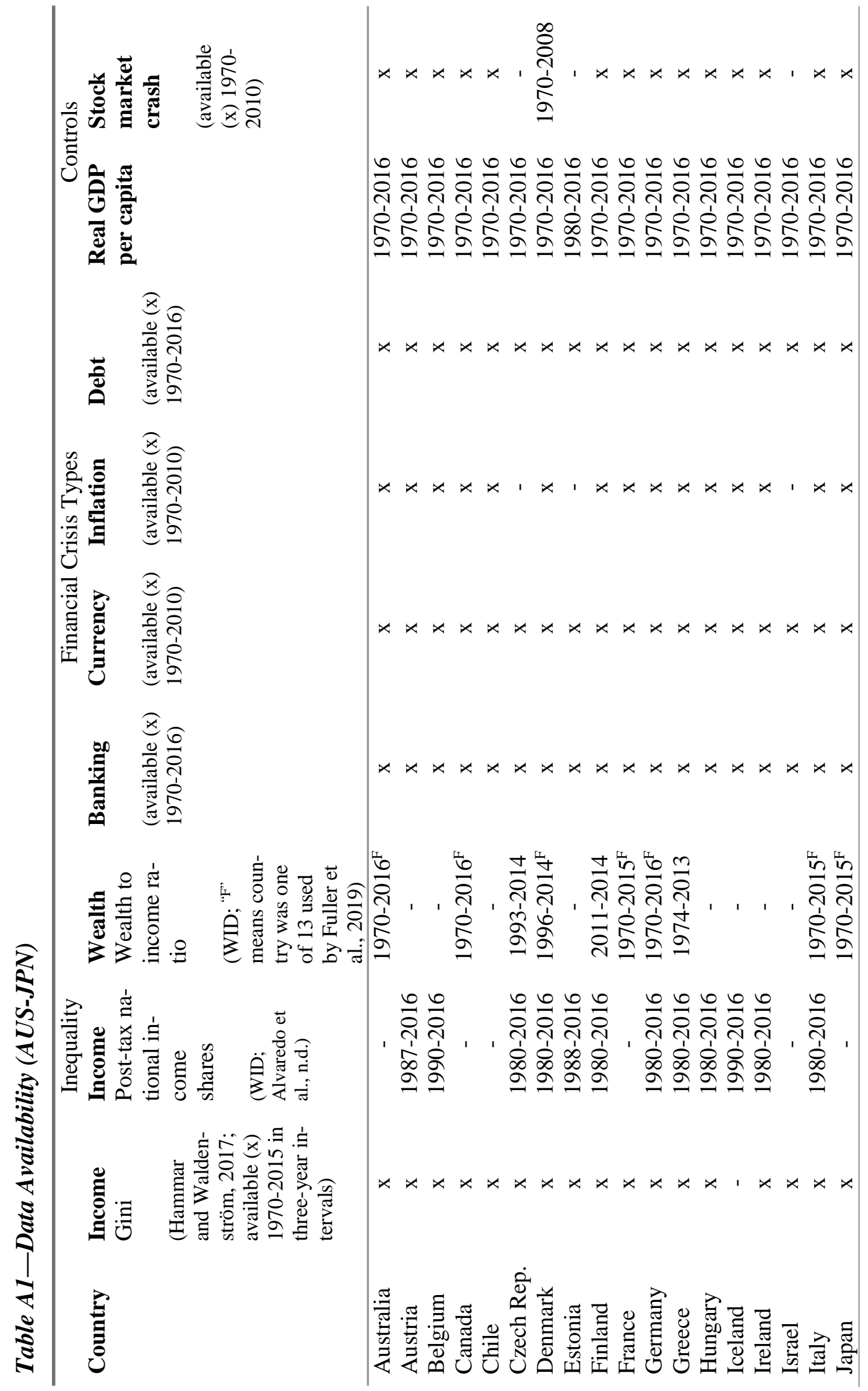




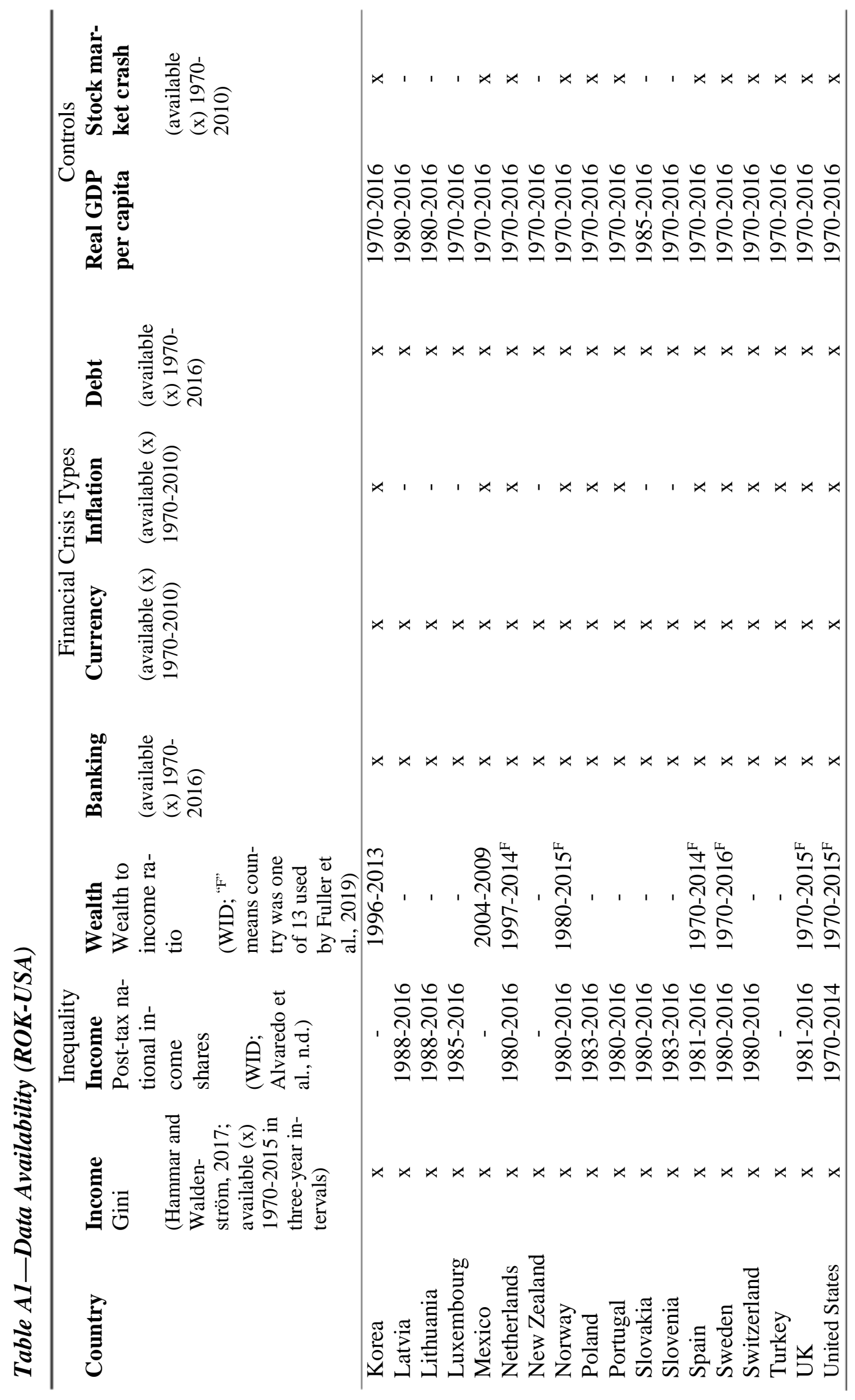

Note that "government ideology" is available for all countries but that some country-year observations are missing from the original DPI2017 dataset following no discernible system. 
A2. CRISIS OCCURRENCE BY TYPE AND COUNTRY

Table A2-Crisis Occurrence by Type and Country (AUS-JPN)

\begin{tabular}{|c|c|c|c|c|}
\hline Country & $\begin{array}{l}\text { Banking } \\
\text { Crisis }\end{array}$ & $\begin{array}{l}\text { Currency } \\
\text { Crisis }\end{array}$ & $\begin{array}{l}\text { Inflation } \\
\text { Crisis }\end{array}$ & Debt Crisis \\
\hline Australia & & & 1975 & \\
\hline Austria & 2008-2012 & & & \\
\hline Belgium & 2008-2012 & & & \\
\hline \multicolumn{5}{|l|}{ Canada } \\
\hline Chile & $\begin{array}{l}1976, \\
1981-1985\end{array}$ & 1972, 1982 & $\begin{array}{l}1970-1980, \\
1983,1985, \\
1990-1991\end{array}$ & $\begin{array}{l}1972, \\
1974-1975, \\
1983-1990\end{array}$ \\
\hline \multicolumn{5}{|c|}{ Czech Rep. } \\
\hline Denmark & 2008-2009 & & & \\
\hline Estonia & 1992-1994 & 1992 & & \\
\hline Finland & 1991-1995 & 1993 & & \\
\hline \multicolumn{5}{|l|}{ France } \\
\hline Germany & 2008-2009 & & & \\
\hline Greece & 2008-2012 & 1983 & 1986, 1990 & $2012-2016$ \\
\hline Hungary & 1991-1995 & & $\begin{array}{l}\text { 1990-1993, } \\
1995-1996\end{array}$ & \\
\hline Iceland & 2008-2012 & $\begin{array}{l}\text { 1975, 1981, } \\
\text { 1989, } 2008\end{array}$ & $\begin{array}{l}1970, \\
1974-1986, \\
1988-1989\end{array}$ & \\
\hline Ireland & 2008-2012 & & 1975, 1981 & \\
\hline Israel & 1983-1986 & $\begin{array}{l}1975,1980, \\
1985\end{array}$ & & \\
\hline Italy & 2008-2009 & 1981 & 1974, 1980 & \\
\hline Japan & 1997-2001 & & 1974 & \\
\hline
\end{tabular}

Note: The data on the occurrence of these four types of financial crises is taken from datasets by Reinhart and Rogoff (2011) and Laeven and Valencia (2018). 
Table A2-Crisis Occurrence by Type and Country (ROK-USA)

\begin{tabular}{|c|c|c|c|c|}
\hline Country & $\begin{array}{l}\text { Banking } \\
\text { Crisis }\end{array}$ & $\begin{array}{l}\text { Currency } \\
\text { Crisis }\end{array}$ & $\begin{array}{l}\text { Inflation } \\
\text { Crisis }\end{array}$ & Debt Crisis \\
\hline Korea & 1997-1998 & 1998 & $\begin{array}{l}1974, \\
1980-1981\end{array}$ & \\
\hline Latvia & 2008-2012 & 1992 & & \\
\hline Lithuania & 1995-1996 & 1992 & & \\
\hline Luxembourg & 2008-2012 & & & \\
\hline Mexico & $\begin{array}{l}\text { 1981-1985, } \\
1994-1996\end{array}$ & $\begin{array}{l}\text { 1977, 1982, } \\
1995\end{array}$ & $\begin{array}{l}1976-1977, \\
1980-1991, \\
1995-1997\end{array}$ & $1982-1990$ \\
\hline Netherlands & 2008-2009 & & & \\
\hline New Zealand & & 1984 & & \\
\hline Norway & 1991-1993 & & & \\
\hline Poland & 1992-1994 & & $\begin{array}{l}\text { 1981-1984, } \\
1987-1995\end{array}$ & 1981-1994 \\
\hline Portugal & $2008-2012$ & 1983 & $\begin{array}{l}1974, \\
1982-1984\end{array}$ & \\
\hline Slovakia & 1998-2002 & & & \\
\hline Slovenia & $\begin{array}{l}1992, \\
2008-2012\end{array}$ & & & \\
\hline Spain & $\begin{array}{l}\text { 1977-1981, } \\
2008-2012\end{array}$ & 1983 & 1977 & \\
\hline Sweden & 1991-1995 & 1993 & $1977-2003$ & \\
\hline \multicolumn{5}{|l|}{ Switzerland } \\
\hline Turkey & $\begin{array}{l}1982-1984, \\
2000-2001\end{array}$ & $\begin{array}{l}\text { 1978, 1984, } \\
\text { 1991, 1996, } \\
2001\end{array}$ & & $\begin{array}{l}1978-1979 \\
1982,2001\end{array}$ \\
\hline UK & 2007-2011 & & 1975 & \\
\hline United States & $2006-2010$ & & & \\
\hline
\end{tabular}

Note: The data on the occurrence of these four types of financial crises is taken from datasets by Reinhart and Rogoff (2011) and Laeven and Valencia (2018). 


\section{A3. FINANCIAL CRISIS TYPES AND INCOME INEQUALITY: INCOME SHARES}

As announced in the main part of the paper, we cannot confirm the findings about the effects of the four different types of financial crises on income inequality using the post-tax income share data. Table A3 displays the parametric results of the DD estimation specified in Eq. (1), this time using the income shares of the top percentile and the top decile excluding the top percentile as the outcome variables respectively. Tables A4a and A4b show the results of the estimations using each of the ten deciles. In this analysis, the number of countries under consideration is further constrained by data availability. This also leads to Poland being the only country going through a debt crisis in the period covered by the sample used for the analysis. We thus refrain from including debt crises in our specification and exclude Poland in order for it not to confound the results. Table A3 shows that there are, if at all, marginal effects of the three remaining types of financial crises on the income shares of the top earners. The income share of the upper middle class decreases by around half a percentage point in banking crisis years although the effect is not robust to the inclusion of country-specific time trends. For inflation crises, no significant effect is discernible. With respect to currency crises, the results from column (3) suggest a small, negative effect of currency crises on the income shares of the rich and thus decreasing income inequality. At first sight, this contradicts the findings from the analysis of the effect on the Gini coefficient. We discuss these discrepancies in the "Discussion and Conclusion” section in the main part of the paper. 
Table A3-Financial Crisis Types and Top Income Shares

\begin{tabular}{|c|c|c|c|c|}
\hline & \multicolumn{4}{|c|}{ Income shares } \\
\hline & $\begin{array}{l}\text { Top1 } \\
\text { (1) }\end{array}$ & $\begin{array}{c}\text { Top10 } \\
\text { excl. Top1 } \\
\text { (2) }\end{array}$ & $\begin{array}{l}\text { Top1 } \\
\text { (3) }\end{array}$ & $\begin{array}{c}\text { Top10 } \\
\text { excl. Top1 } \\
\text { (4) }\end{array}$ \\
\hline Banking Crisis & $\begin{array}{l}-0.002 \\
(0.004)\end{array}$ & $\begin{array}{c}-0.004^{* *} \\
(0.002)\end{array}$ & $\begin{array}{c}0.001 \\
(0.002)\end{array}$ & $\begin{array}{l}-0.000 \\
(0.002)\end{array}$ \\
\hline Currency Crisis & $\begin{array}{c}0.002 \\
(0.004)\end{array}$ & $\begin{array}{l}-0.002 \\
(0.003)\end{array}$ & $\begin{array}{c}-0.004^{* *} \\
(0.002)\end{array}$ & $\begin{array}{l}-0.001 \\
(0.002)\end{array}$ \\
\hline Inflation Crisis & $\begin{array}{c}0.001 \\
(0.002)\end{array}$ & $\begin{array}{l}-0.005 \\
(0.007)\end{array}$ & $\begin{array}{l}-0.002 \\
(0.003)\end{array}$ & $\begin{array}{c}0.001 \\
(0.004)\end{array}$ \\
\hline Real GDP per capita & $\begin{array}{c}0.000 \\
(0.000)\end{array}$ & $\begin{array}{l}-0.000 \\
(0.000)\end{array}$ & $\begin{array}{c}0.000^{* * *} \\
(0.000)\end{array}$ & $\begin{array}{c}0.000^{* * *} \\
(0.000)\end{array}$ \\
\hline Stock Market Crash & $\begin{array}{l}-0.000 \\
(0.002)\end{array}$ & $\begin{array}{l}-0.000 \\
(0.002)\end{array}$ & $\begin{array}{l}-0.001 \\
(0.001)\end{array}$ & $\begin{array}{l}-0.001 \\
(0.001)\end{array}$ \\
\hline Country-specific trends & No & No & Yes & Yes \\
\hline $\begin{array}{l}\text { Observations } \\
R^{2}\end{array}$ & $\begin{array}{l}516 \\
0.50\end{array}$ & $\begin{array}{l}516 \\
0.36\end{array}$ & $\begin{array}{l}516 \\
0.70\end{array}$ & $\begin{array}{l}516 \\
0.71\end{array}$ \\
\hline
\end{tabular}

Standard errors in parentheses

${ }^{*} \mathrm{p}<0.10,{ }^{* *} \mathrm{p}<0.05, * * * \mathrm{p}<0.01$

Note: The table reports regression DD estimates of the effects of the different types of financial crises on the top income shares. All models include country and year fixed effects. Robust standard errors are clustered at the country level. The sample used contains the countries and years for which information on the three crisis types and income shares is available. See Appendix Table A1. Debt crises are excluded as only one country, Poland, goes through a debt crisis. Poland is omitted from this analysis so that it does not confound the results. 


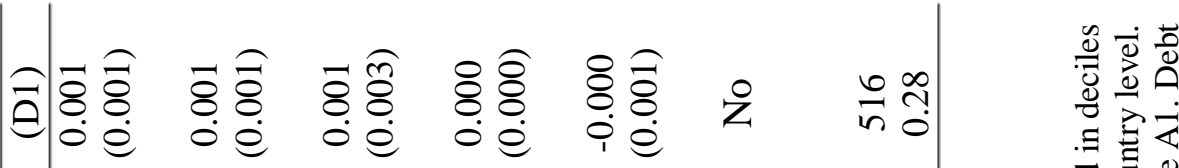

约造言

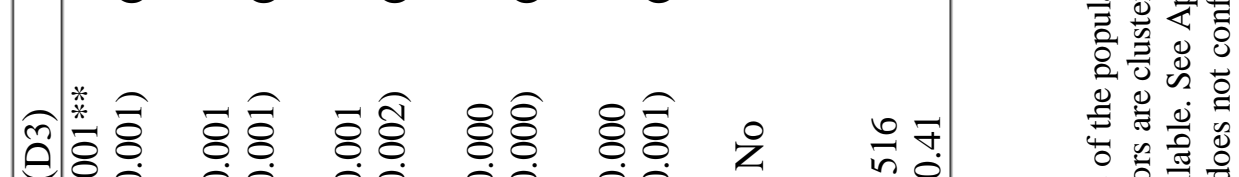

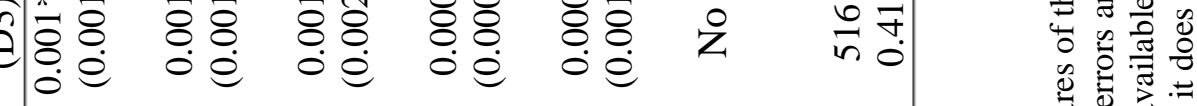

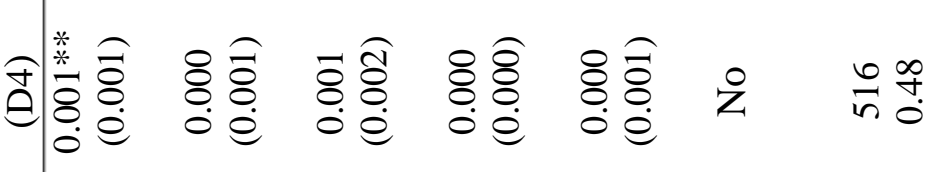

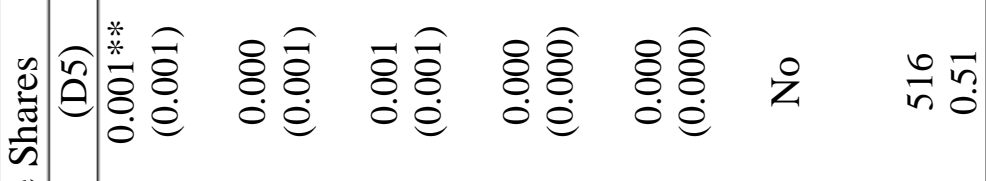

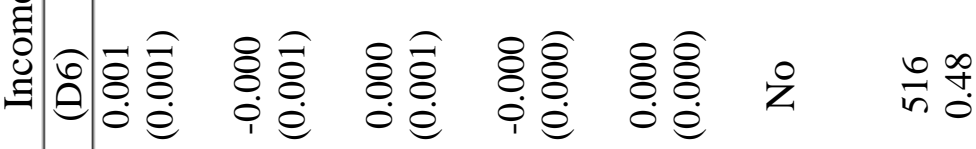

玄

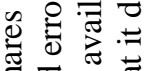

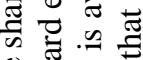

范焉 क

㻤 $\frac{\pi}{n} \cdot \frac{n}{n}$

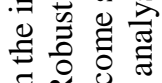

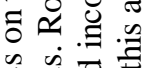

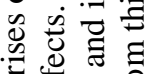

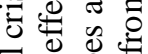

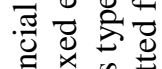
范崀 常苟

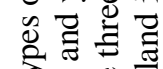
空㲾要

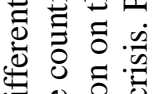

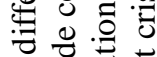

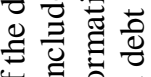

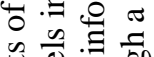

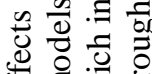

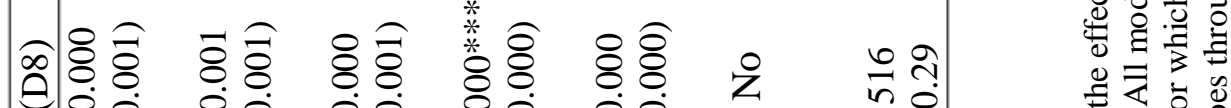

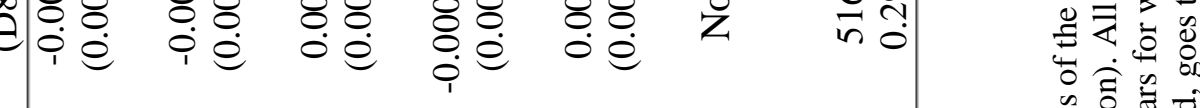

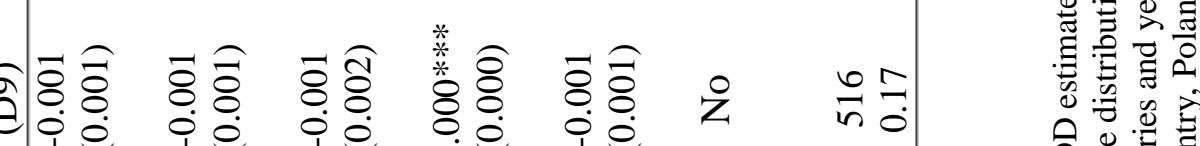

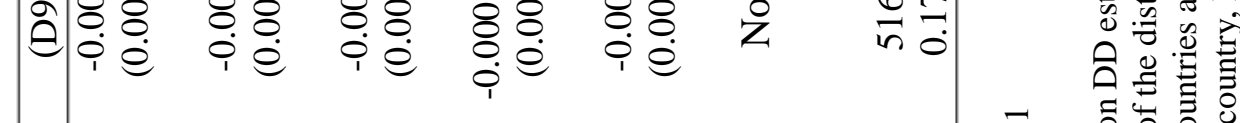
U

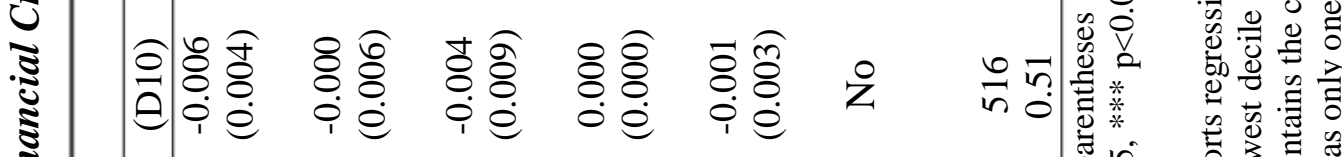
列

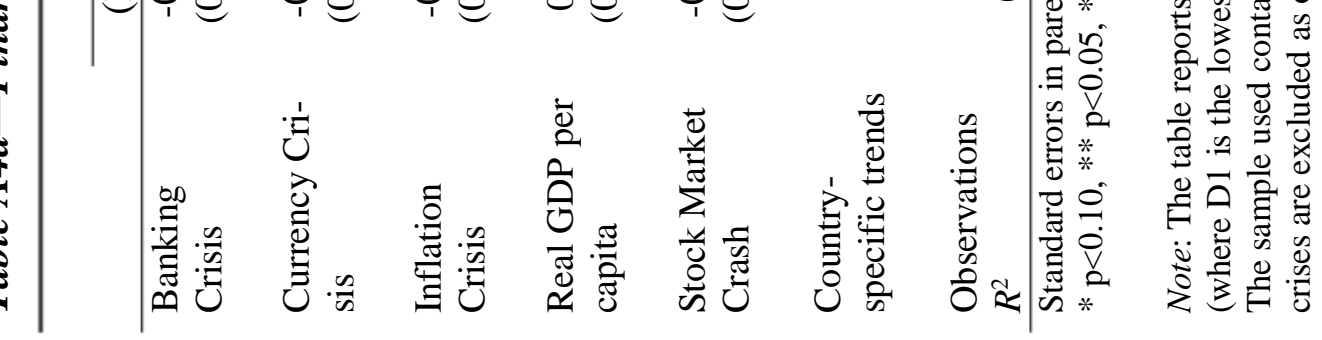




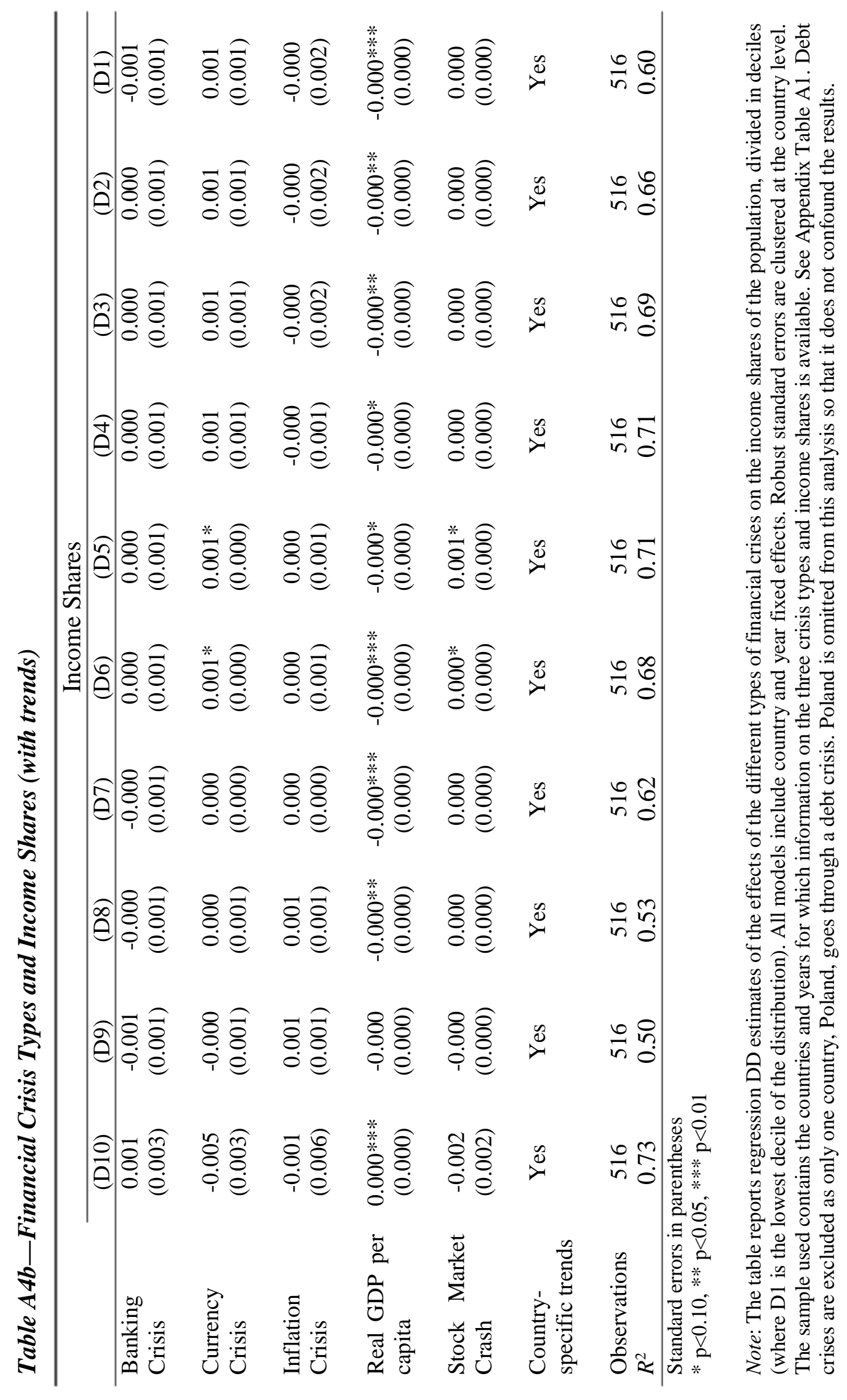




\section{A4. ROBUSTNESS CHECKS}

We conduct a number of robustness checks for various purposes. First, we run the main econometric specification for each crisis type individually, once with and once without countryspecific linear time trends. We always include the two control variables. As explained before, we automatically control for the occurrence of the other financial crisis types in our main specification by including all four types at the same time. Repeating the exercise for each type individually allows us to see whether a potential interdependency between the crisis types influences the results in our main specification. We present the regression results using the Gini coefficient in Table A5, and using the wealth-to-income ratio in Table A6. Comparing these results to that of the main specification, Table 2 and Table 4, one can see that the coefficients do not change considerably depending on whether the crisis types are included in a specification individually or together. The coefficients on banking and inflation crises in a regression using the Gini coefficient change somewhat. However, they are small and insignificant in both cases and we refrain from interpreting them either way. Overall, this robustness check suggests that a potential interdependency between the crisis types is of little to no importance in our model.

Second, we repeat our main specification, but instead of using variables capturing all crisis years of each crisis type, we use variables only capturing the onset year of each crisis type. This gives us preliminary insights with respect to possibly diverging effects of the same crisis type throughout a crisis period. Of course, the statistical power of these models is likely to be even more limited given that the number of years coded as crisis years is further restricted. We present the effects of crisis onset years on income inequality (measured by the Gini coefficient) in Table A7. The coefficient on the onset of banking crises is insignificant. However, its sign is robust to the inclusion of country-specific linear time trends, at least indicatively suggesting negative effects of banking crises on income inequality in the first year of a crisis. Currency crises are always coded as lasting only a single year in the sample, which is why the coefficients do not change considerably in the onset-year-only models. Though statistically insignificant, the coefficients on the onset of inflation crises suggests a positive effect of this crisis type on income inequality in the first year of the crisis. Debt crisis onset years capture the years of sovereign default or of debt restructuring. The coefficients on this crisis type are even less reliable than the coefficients from the main analysis. This is comprehensible considering that only nine years are coded as crisis years in this robustness specification. Table A8 in the appendix shows the estimated effects of crisis onset years on wealth inequality (measured by the wealthto-income ratio). The coefficient on banking crisis onset years is, though statistically insignificant, is positive and relatively robust to the inclusion of country-specific linear time trends. This 
hints at a small positive effect of banking crisis on wealth inequality in their onset years. Keeping in mind the results from the main specification, these insights again point to the need to examine the $\Lambda$-shaped pattern of wealth inequality throughout banking crisis episodes, discussed above. Overall, the findings from this robustness check suggest that the effect of the different financial crisis types on income and wealth inequality varies at least somewhat throughout crisis episodes.

Third, we exclude the possibility that the different results from the regressions using the Gini coefficient and those using the income shares are due to the income share results being based on a smaller sample of countries and years. We do so by restricting the Gini coefficient sample to those countries and years for which we have data on income shares. This restricted sample includes mostly western and central European countries and the United States, usually since 1980. We also omit Poland, same as we do in the estimations using the income shares as the outcome variable. Debt crises thus drop out of the estimation. See Table A9 for the results. The table generally confirms the results from the unrestricted sample for the remaining three crisis types. Interestingly, currency crises have an even stronger effect on income inequality in the countries in the restricted sample. Related to this robustness check, it can be criticised that the sample used in this paper is unbalanced. However, most of the unbalance is due to the sample being a combination of different datasets that cover different countries and different periods. Considering the individual inequality variables, the unbalance is most likely attributable to the countries in question not collecting or publishing the data earlier. In other words, it is very unlikely that the data does not exist because a country seeks to hide a particularly high level of inequality, for example. We also presume this because once a variable is provided for a country, it is not provided intermittently but consistently. We thus claim that the missing data is missing at random.

Finally, we rerun the main specification using the Gini coefficient as the outcome variable but additionally include interaction terms for twin crises, so between each crisis type and each of the other three crisis types, resulting in six interaction effects. The coefficients on the interaction terms capture the additional effect when two crisis types occur together. We exclude triplet crises because there are very few of them. Additionally, when including triplet crises, the interpretation of coefficients becomes arduous. Assume there is a triplet crisis between a banking, a currency, and an inflation crisis. The effect of a banking crisis would then be captured by four coefficients: the coefficient on the individual crisis, the two twin crises, and the triplet crisis. The results of the regression including the twin-crises interaction effects are shown in 
Table A10. Interestingly, an inflation crisis occurring at the same time as a currency crisis renders the effect of the currency crisis null and void. Another noteworthy observation is the change occurring for the coefficient on debt crises, which becomes positive and statistically significant—depending on the model at least at the ten percent level. This would suggest that, absent any other crisis type, debt crises have a positive effect on income inequality after all. However, almost all debt crises in our sample occur in parallel to other crisis types such that this situation hardly occurs. The large, negative coefficient on the inflation-debt interaction term shows that the negative effect of debt crises in our main specification was likely due to the simultaneous occurrence of these two crisis types not being captured separately. The results from this specification suggest that banking and debt crises together increase income inequality in the four countries concerned, while inflation and debt crises together decrease it. Overall, two lessons can be learned with respect to debt crises. First, the rare occurrence of this crisis type makes it very difficult to draw generalizable conclusions concerning its effect. Second, the analysis of the interaction between debt crises and other crisis types is more than warranted. We refrain from integrating interaction terms between the crisis types in the specification applying the wealth-to-income ratio because given the limited sample, only two twin crises occur. 


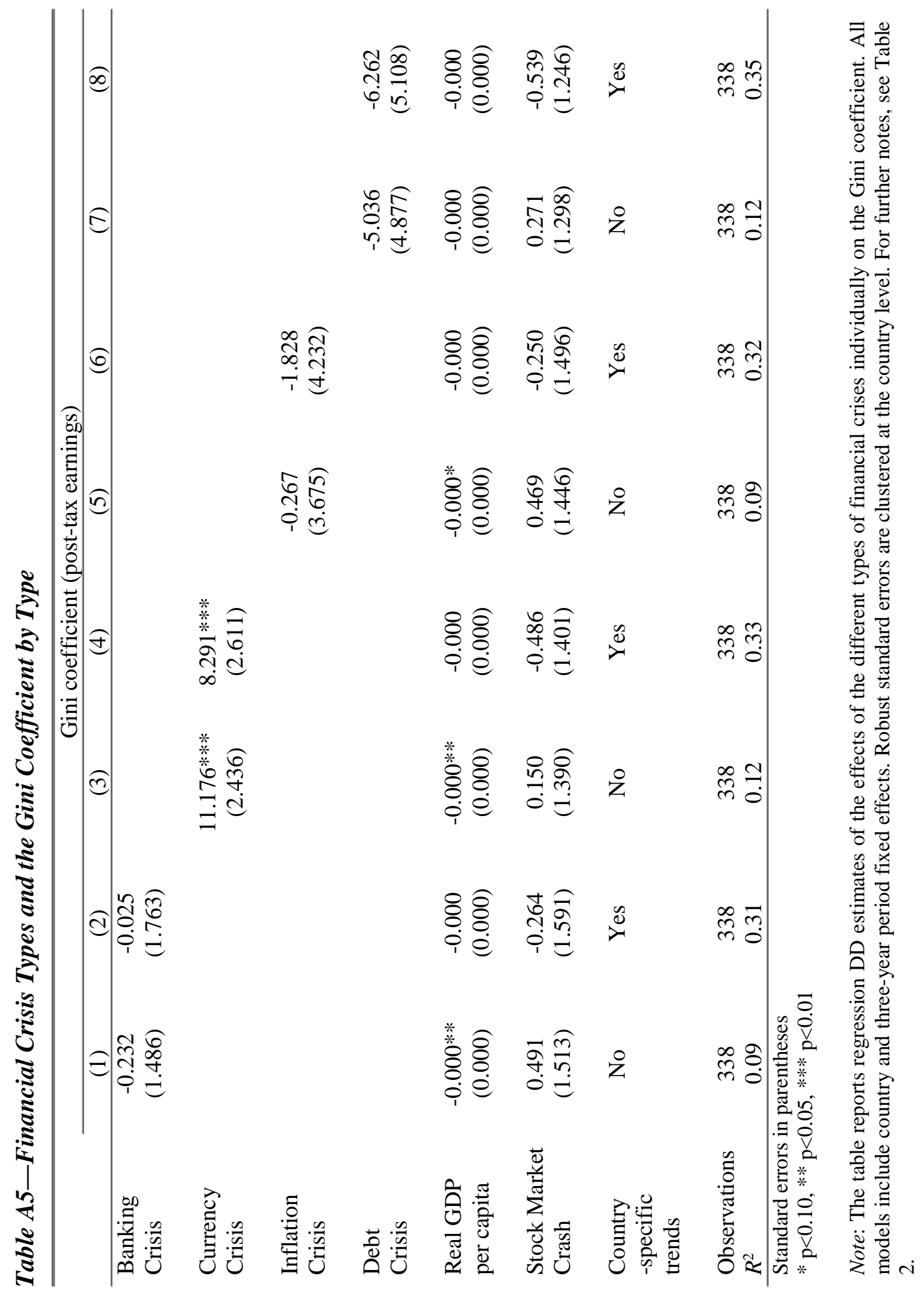


Table A6-Financial Crisis Types and the Wealth-to-Income Ratio by Type

\begin{tabular}{|c|c|c|c|c|c|c|}
\hline & \multicolumn{6}{|c|}{ Wealth-to-Income Ratio } \\
\hline & (1) & (2) & (3) & (4) & (5) & (6) \\
\hline $\begin{array}{l}\text { Banking } \\
\text { Crisis }\end{array}$ & $\begin{array}{l}-0.022 \\
(0.217)\end{array}$ & $\begin{array}{c}0.008 \\
(0.229)\end{array}$ & & & & \\
\hline $\begin{array}{l}\text { Currency } \\
\text { Crisis }\end{array}$ & & & $\begin{array}{c}-0.399 * * * \\
(0.116)\end{array}$ & $\begin{array}{l}-0.111 \\
(0.136)\end{array}$ & & \\
\hline $\begin{array}{l}\text { Inflation } \\
\text { Crisis }\end{array}$ & & & & & $\begin{array}{c}-0.419 * * * \\
(0.132)\end{array}$ & $\begin{array}{l}-0.037 \\
(0.059)\end{array}$ \\
\hline $\begin{array}{l}\text { Real GDP per } \\
\text { capita }\end{array}$ & $\begin{array}{c}0.000 \\
(0.000)\end{array}$ & $\begin{array}{c}0.000 \\
(0.000)\end{array}$ & $\begin{array}{c}0.000 \\
(0.000)\end{array}$ & $\begin{array}{c}0.000 \\
(0.000)\end{array}$ & $\begin{array}{c}0.000 \\
(0.000)\end{array}$ & $\begin{array}{c}0.000 \\
(0.000)\end{array}$ \\
\hline $\begin{array}{l}\text { Stock Market } \\
\text { Crash }\end{array}$ & $\begin{array}{c}0.113 \\
(0.127)\end{array}$ & $\begin{array}{c}0.133 \\
(0.081)\end{array}$ & $\begin{array}{c}0.114 \\
(0.140)\end{array}$ & $\begin{array}{c}0.135 \\
(0.089)\end{array}$ & $\begin{array}{c}0.110 \\
(0.142)\end{array}$ & $\begin{array}{c}0.134 \\
(0.088)\end{array}$ \\
\hline $\begin{array}{l}\text { Country } \\
\text {-specific } \\
\text { trends }\end{array}$ & No & Yes & No & Yes & No & Yes \\
\hline $\begin{array}{l}\text { Observations } \\
R^{2}\end{array}$ & $\begin{array}{l}468 \\
0.61\end{array}$ & $\begin{array}{l}468 \\
0.73\end{array}$ & $\begin{array}{l}468 \\
0.61\end{array}$ & $\begin{array}{l}468 \\
0.73\end{array}$ & $\begin{array}{l}468 \\
0.61\end{array}$ & $\begin{array}{l}468 \\
0.73\end{array}$ \\
\hline
\end{tabular}

Standard errors in parentheses

${ }^{*} \mathrm{p}<0.10, * * \mathrm{p}<0.05, * * * \mathrm{p}<0.01$

Note: The table reports regression DD estimates of the effects of the different types of financial crises individually on the wealth-to-income ratio. All models include country and year fixed effects. Robust standard errors are clustered at the country level. The sample covers Australia, Canada, Denmark, France, Germany, Italy, Japan, Netherlands, Norway, Spain, Sweden, United Kingdom, and the United States. The years for which the ratio is available for these countries can be taken from Appendix Table A1. 
Table A7-Onset of Financial Crisis Types and the Gini Coefficient

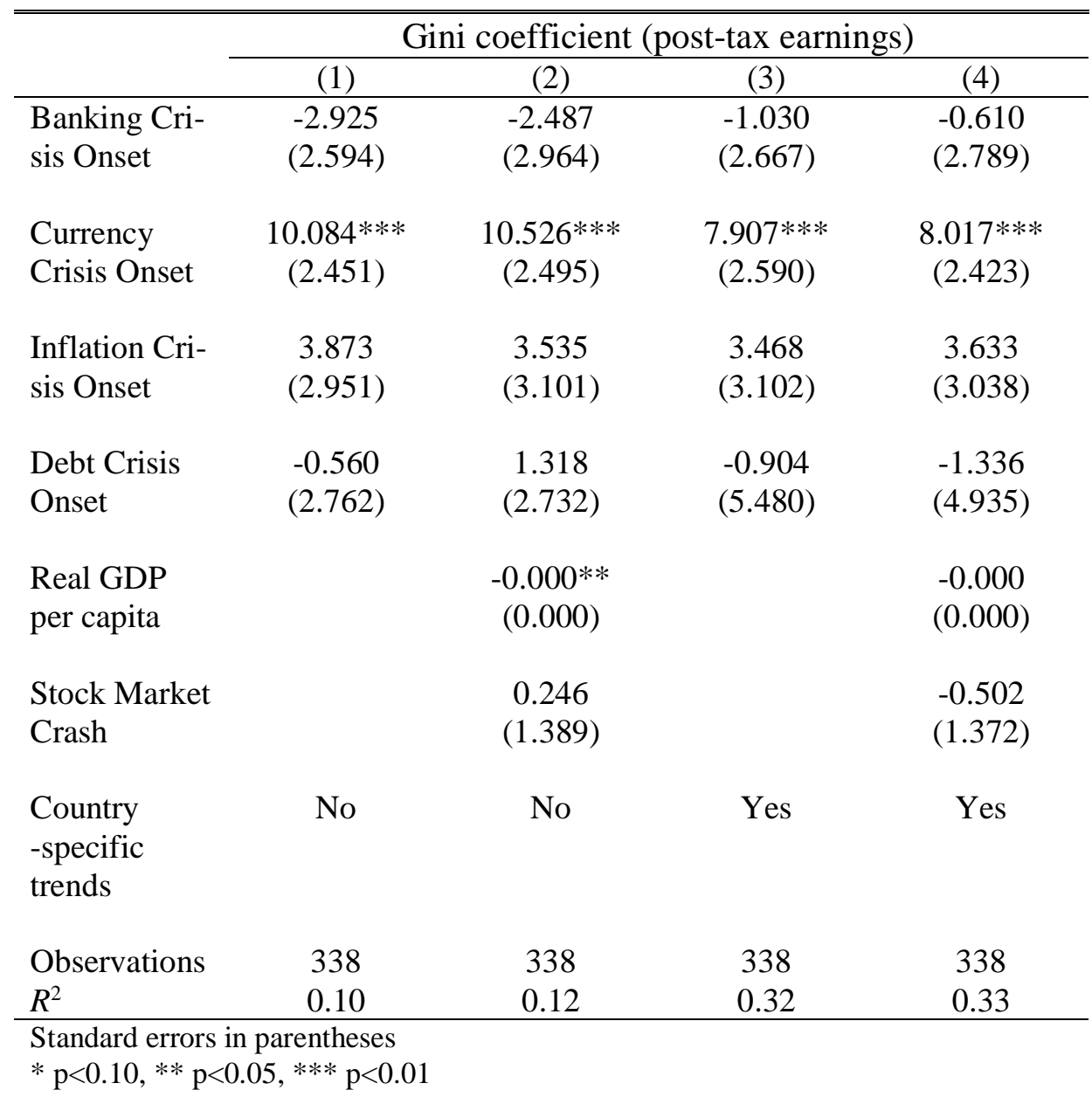

Note: The table reports regression DD estimates of the effects of the onset of the different types of financial crises on the Gini coefficient. All models include country and three-year period fixed effects. Robust standard errors are clustered at the country level and reported. For further notes, see Table 2. 
Table A8-Onset of Financial Crisis Types and the Wealth-to-Income Ratio

\begin{tabular}{lcccc}
\hline & \multicolumn{4}{c}{ Wealth-to-Income Ratio } \\
\cline { 2 - 5 } & $(1)$ & $(2)$ & $(3)$ & $(4)$ \\
\hline Banking Crisis & 0.269 & 0.277 & 0.193 & 0.207 \\
Onset & $(0.214)$ & $(0.215)$ & $(0.198)$ & $(0.181)$ \\
Currency Crisis & $-0.384^{* * *}$ & $-0.399^{* * *}$ & -0.163 & -0.110 \\
Onset & $(0.111)$ & $(0.115)$ & $(0.176)$ & $(0.135)$ \\
Inflation Crisis & $-0.472^{* * *}$ & $-0.470^{* * *}$ & -0.094 & -0.078 \\
Onset & $(0.136)$ & $(0.137)$ & $(0.101)$ & $(0.101)$ \\
& & & & \\
Real GDP per & & 0.000 & & 0.000 \\
capita & & $(0.000)$ & & $0.000)$ \\
& & & & 0.128 \\
Stock Market & & 0.105 & & $(0.084)$ \\
Crash & & & & Yes \\
Country-specific & No & No & Yes & \\
trends & & & & 468 \\
Observations & 470 & 468 & 470 & 0.73 \\
$R^{2}$ & 0.61 & 0.61 & 0.71 & \\
\hline
\end{tabular}

Standard errors in parentheses

${ }^{*} \mathrm{p}<0.10,{ }^{* *} \mathrm{p}<0.05,{ }^{* * *} \mathrm{p}<0.01$

Note: The table reports regression DD estimates of the effects of the onset of the different types of financial crises on the wealth-to-income ratio. All models include country and year fixed effects. Robust standard errors are clustered at the country level. The sample covers Australia, Canada, Denmark, France, Germany, Italy, Japan, Netherlands, Norway, Spain, Sweden, United Kingdom, and the United States. The years for which the ratio is available for these countries can be taken from Appendix Table A1. 
Table A9-Financial Crisis Types and the Gini Coefficient, Restricted Sample

\begin{tabular}{lcccc}
\hline & \multicolumn{4}{c}{ Gini coefficient (post-tax earnings) } \\
\cline { 2 - 5 } & $(1)$ & $(2)$ & $(3)$ & $(4)$ \\
\hline Banking & -1.876 & $-2.221^{*}$ & 0.566 & 0.439 \\
Crisis & $(1.303)$ & $(1.256)$ & $(1.465)$ & $(1.259)$ \\
& & & & \\
Currency & $13.837^{* *}$ & $16.269^{* * *}$ & $11.538^{* * *}$ & $11.771^{* * *}$ \\
Crisis & $(5.179)$ & $(4.530)$ & $(3.669)$ & $(3.874)$ \\
& & & & -1.393 \\
Inflation & 0.209 & -0.280 & -0.828 & $(2.195)$ \\
Crisis & $(2.491)$ & $(2.078)$ & $(3.038)$ & -0.000 \\
Real GDP per & & -0.000 & & $(0.000)$ \\
capita & & $(0.000)$ & & -2.248 \\
& & & & $(1.699)$ \\
Stock Market & & $-3.015^{*}$ & & Yes \\
Crash & & $(1.558)$ & & \\
Country-specific & No & No & Yes & 155 \\
trends & & & & 0.52 \\
Observations & 155 & 155 & 155 & 0.49 \\
$R^{2}$ & 0.23 & 0.28 & & \\
\hline
\end{tabular}

Standard errors in parentheses

${ }^{*} \mathrm{p}<0.10, * * \mathrm{p}<0.05$, *** $\mathrm{p}<0.01$

Note: The table report regression DD estimates of the effects of the different types of financial crises on the Gini coefficient. All models include country and three-year period fixed effects. Robust standard errors are clustered at the country level and reported in parentheses. The sample used contains the countries and respective years for which information on the WID income shares is available, except Iceland for which the Gini coefficient is missing. See Appendix Table A1. Same as in the estimations using income shares, debt crises are excluded as only one Poland goes through a debt crisis. Poland is omitted from the analysis. Crises can take on four values $(0,1 / 3,2 / 3$, or 1$)$ depending on how many years are coded as crisis years within the three-year period in question. In principle, the three-year periods cover the years 1971 to 2009. 
Table A10-Financial Crisis Types and the Gini Coefficient, Interaction Terms

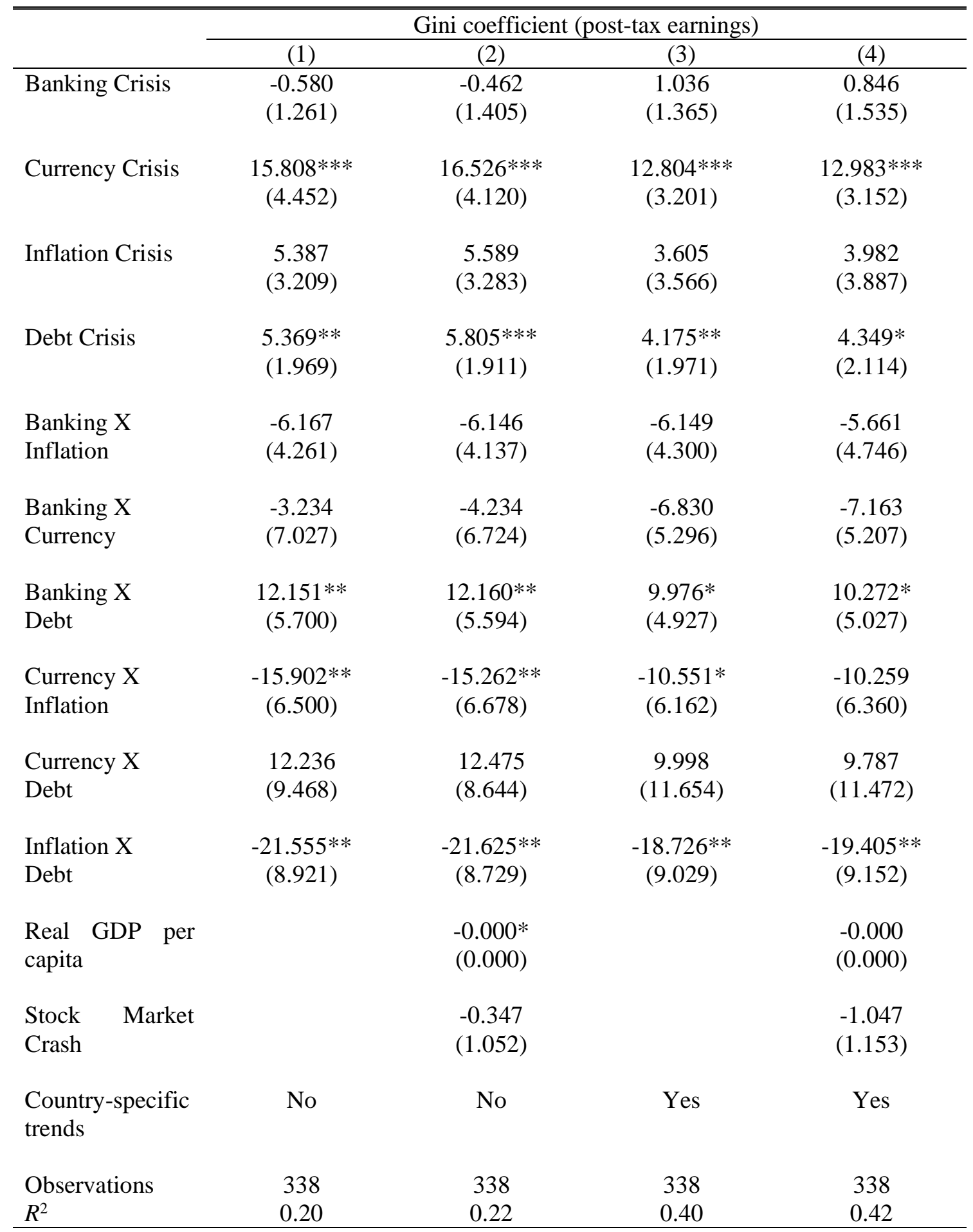

Standard errors in parentheses

${ }^{*} \mathrm{p}<0.10,{ }^{* *} \mathrm{p}<0.05, * * * \mathrm{p}<0.01$

Note: The table reports regression DD estimates of the effects of the onset of the different types of financial crises on the Gini coefficient. All models include country and three-year period fixed effects. Robust standard errors are clustered at the country level. As before, the crises can take on four values $(0,1 / 3$, $2 / 3$, or 1 ). The interactions are coded in the same way. They are thus interactions of crisis years and not of the shares in a three-year period. For further notes, see Table 2. 
